
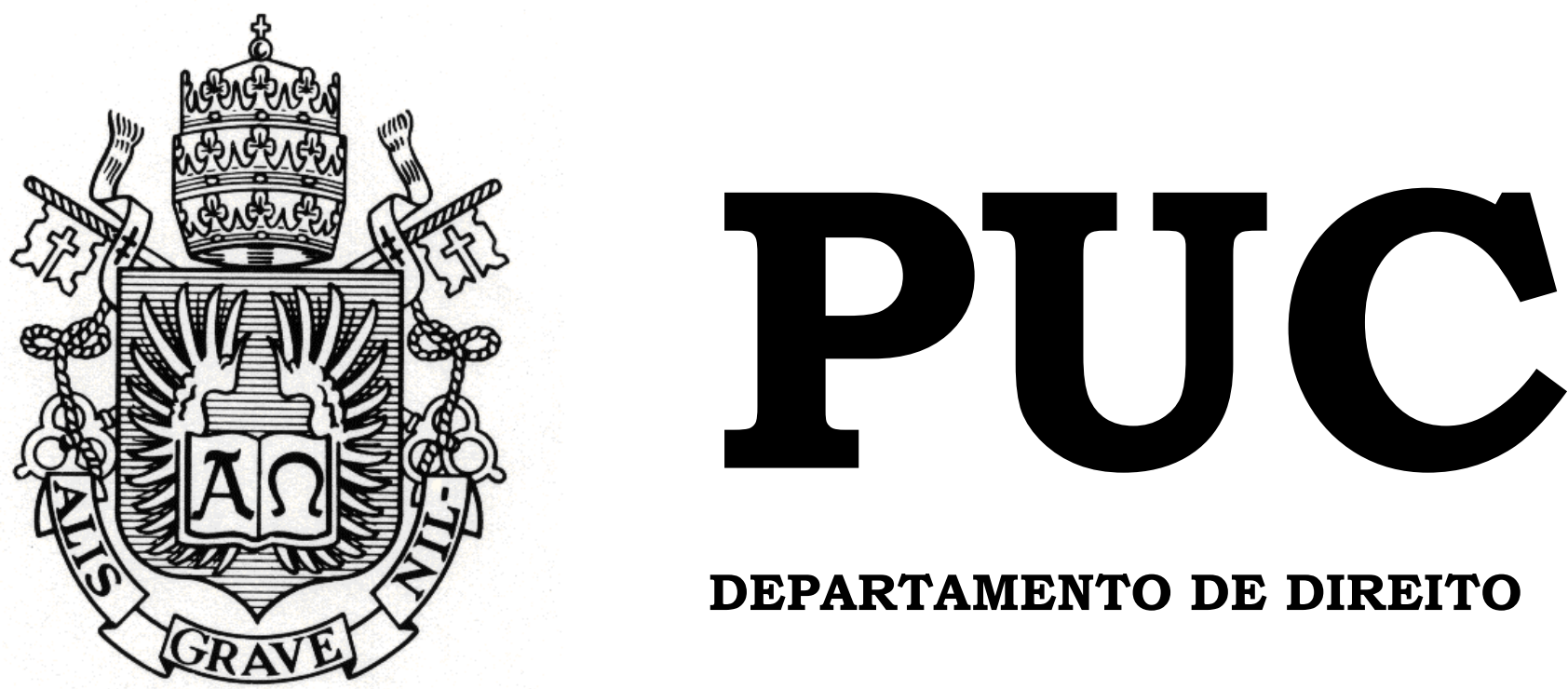

DEPARTAMENTO DE DIREITO

\title{
REDUÇÕES CERTIFICADAS DE EMISSÕES (RCEs): TRATAMENTO JURÍDICO E REGULAÇÃO NO MERCADO DE CAPITAIS
}

por

\author{
JOÃO PAULO NOGUEIRA BARROS
}

ORIENTADOR: Julian Fonseca Peña Chediak

2011.2

PONTIFÍCIA UNIVERSIDADE CATÓLICA DO RIO DE JANEIRO

RUA MARQUÊS DE SÃO VICENTE, 225 - CEP 22453-900

RIO DE JANEIRO - BRASIL 


\section{REDUÇÕES CERTIFICADAS DE EMISSÕES (RCES): TRATAMENTO JURÍDICO E REGULAÇÃO NO MERCADO DE CAPITAIS}

por

\section{JOÃO PAULO NOGUEIRA BARROS}

Monografia apresentada ao Departamento de Direito da Pontificia Universidade Católica do Rio de Janeiro como exigência final para obtenção do Título de Bacharel em Direito.

Orientador: Julian Fonseca Peña Chediak

2011.2 
Dedico esta monografia a todos aqueles que me incentivaram a buscar meus ideais e de alguma forma contribuíram para meu crescimento acadêmico e profissional. 


\section{RESUMO}

O homem, na sua jornada contínua rumo ao desenvolvimento econômico, têm ignorado preceitos fundamentais de conscientização ecológica em detrimento da industrialização e do avanço tecnológico. As ações antrópicas neste sentido tem se mostrado irracionais, afetando severamente a estabilidade climática do planeta. Ao se darem conta de que os efeitos da degradação ambiental colocavam em risco a própria existência humana, as autoridades internacionais iniciaram discussões e negociações voltadas à garantia da sustentabilidade da vida na terra. Neste contexto foi elaborado em 1997 o tratado conhecido Protocolo de Quito, até hoje considerado o mais importante acordo multilateral sobre mudanças climáticas e desenvolvimento sustentável. O protocolo inaugura uma nova fase da direito ambiental internacional ao estabelecer compromissos específicos de redução de emissões de gases do efeito estufa. No entanto, a novidade mais comemorada do tratado foi a criação dos chamados mecanismos de flexibilização, instrumentos de mercado que auxiliam o cumprimento das metas de redução nele impostas. Para o Brasil, o interesse se volta para o MDL, mecanismo através do qual é facultado ao país implementar projetos com potencial de geração de títulos representativos de redução de emissões (RCEs), as quais podem ser negociadas com as partes interessadas em utiliza-las no cumprimento de seus compromissos ambientais. Em virtude da recente introdução destes conceitos no cenário econômico internacional e considerando a importância deste novo regime para o Brasil, o presente trabalho propõe uma reflexão acerca da definição da natureza jurídica das RCEs e sua regulação no mercado de valores mobiliários, tendo como propósito apresentar alternativas que tornem o país mais eficiente no setor e possibilitem melhor aproveitamento deste mercado nascente.

Palavras Chave: Reduções Certificadas de Emissões, Créditos de Carbono, Mecanismos de Desenvolvimento Limpo, Natureza Jurídica, Mercado de Capitais, Regulação Econômica 


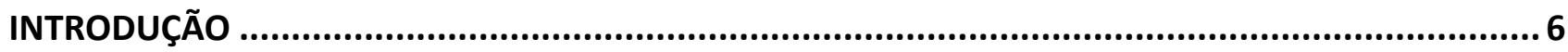

1. EVOLUÇÃO HISTÓRICA DO DESENVOLVIMENTO SUSTENTÁVEL............................................. 11

1.1. A problemática ambiental contemporânea e o desenvolvimento sustentável................ 13

1.2. 0 aquecimento global na agenda internacional .................................................. 16

1.2.1. As Conferencias das Partes (COPs) ........................................................................17

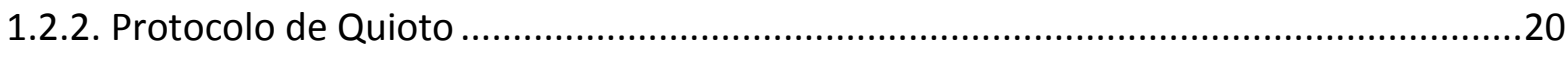

1.3. Mecanismos de Flexibilização ........................................................................................... 23

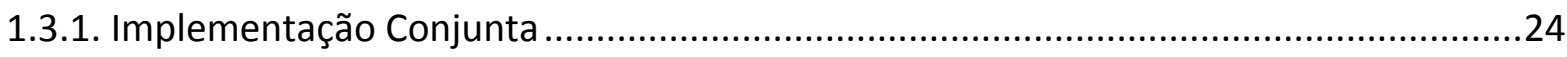

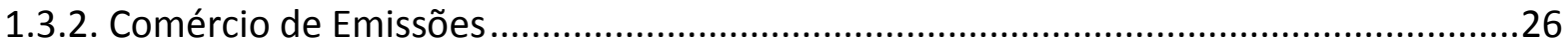

1.3.3. O Mecanismo de Desenvolvimento Limpo (MDL).................................................29

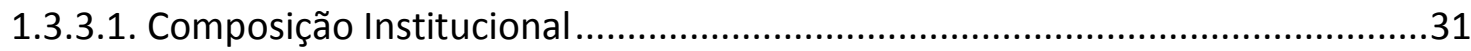

1.3.3.2. Procedimento de Certificação de Projetos ..................................................32

2. DAS REDUÇÕES CERTIFICADAS DE EMISSÕES (RCES) ............................................................. 35

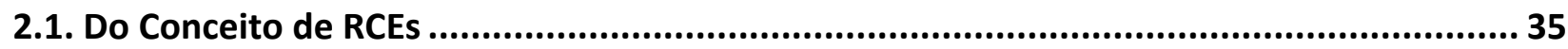

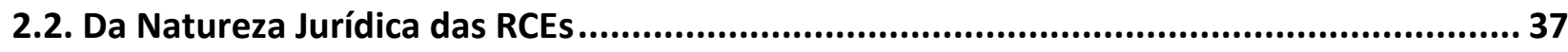

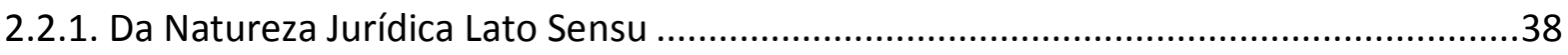

2.2.1.1. Bem Incorpóreo e Intangível ..................................................................39

2.2.1.2. Ativo ou Derivativo .........................................................................41

2.2.2. Da Natureza Jurídica Stricto Sensu ......................................................................44

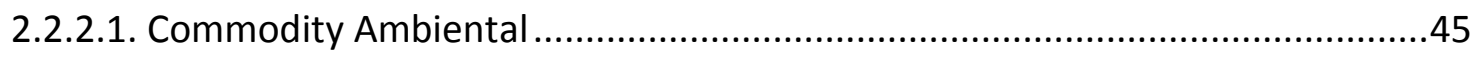

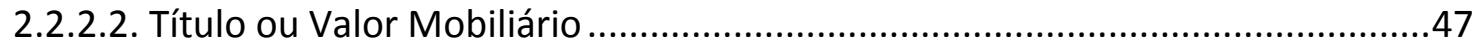

2.2.2.3. Contrato de Prestação de Serviços ...........................................................55

2.3. Classificação das RCES no Direito Comparado............................................................. 57 
3. REGULAMENTAÇÃO DO MERCADO DE CARBONO ........................................................60

3.1. As Espécies de Mercado de Carbono ................................................................ 61

3.1.1. Mercado Formal de Carbono .................................................................... 62

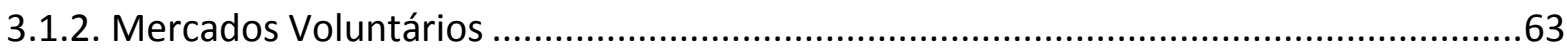

3.2. Estruturas de Mercados Existentes...................................................................... 65

3.2.1. Chicago Climate Exchange - CCX..................................................................66

3.2.2. United Kingdom Emission Trading Scheme - UK ETS ............................................68

3.2.3. European Union Emission Trading System - EU ETS ...........................................69

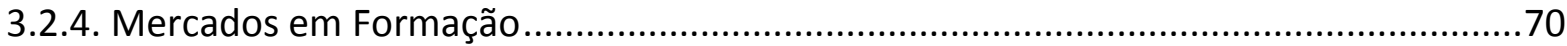

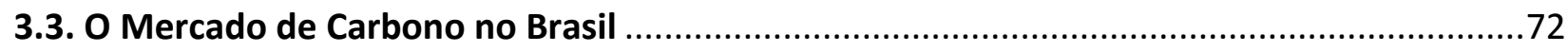

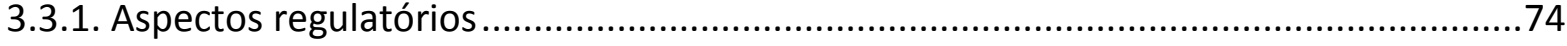

3.3.2. Mercado Brasileiro de Reduções de Emissões - MBRE ............................................75

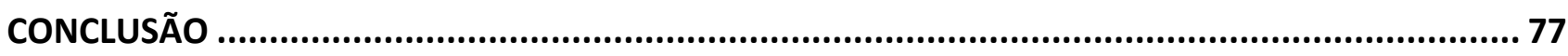

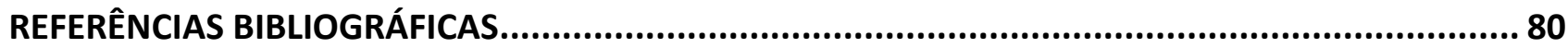




\section{INTRODUÇÃO}

A preocupação com a questão ambiental acompanha o desenvolvimento da sociedade desde o aparecimento das primeiras consequências do processo de devastação do meio ambiente, iniciado com o advento da Revolução Industrial e intensificado pelos demais fenômenos capitalistas posteriores.

Os primeiros períodos da industrialização foram marcados pela dependência da produção mundial em relação aos combustíveis fósseis, o que se explica pelo fato do petróleo e seus derivados serem fontes de energia muito mais eficientes que as tecnologias anteriormente utilizadas. Ocorre, no entanto, que as principais matrizes energéticas utilizadas nesta fase da evolução capitalista representavam potenciais causadores da poluição do ar.

Além de ocasionar diversos danos à saúde dos seres humanos, aumentando o risco de doenças respiratórias, a poluição atmosférica tem relação direta com o aquecimento da superfície terrestre, uma vez que as mesmas fontes de poluentes que contaminam o ar também emitem gases que intensificam o fenômeno natural denominado efeito estufa.

O efeito estufa ocorre de forma natural a partir da passagem de radiação solar pela atmosfera, quando então uma parte desta energia atravessa a atmosfera e atinge a superfície da Terra, enquanto que o restante dos raios emitidos pelo Sol são absorvidos ou diretamente refletidos pela atmosfera. Uma parcela desta energia que é refletida pela superfície terrestre na forma de raios infravermelhos é impedida de deixar a atmosfera e alcançar espaço pela atuação de uma camada formada por elementos químicos conhecidos como gases do efeito estufa (GEE) ${ }^{1}$, que funciona como uma barreira natural contra a dissipação do calor na atmosfera,

\footnotetext{
1 Segundo o Anexo A do Protocolo de Quioto, os GEE são os seguintes:

- dióxido de carbono (CO2);

- metano (CH1);

- óxido nitroso (N2O)

- hidrofluorocarbonos (HFCs)

- perfluorocarbonos (PFCs)

- Hexafluoreto de enxofre (SF6)
} 
contribuindo para a manutenção da temperatura terrestre de forma equilibrada.

Daí conclui-se que o efeito estufa naturalmente concebido não representa um fenômeno prejudicial à vida terrestre, ao contrário, constitui um meio de conservar o nosso planeta de forma habitável. O seguinte enunciado retirado do website ${ }^{2}$ do Ministério de Ciência e Tecnologia descreve com clareza a importância do efeito estufa para a vida na terra: "Se a superfície terrestre pudesse irradiar energia para o espaço livremente, nosso planeta seria um lugar frio e sem vida, tão desolado e estéril quanto Marte."

Os danos gerados pelo efeito estufa decorrem da concentração de GEE na atmosfera acima dos níveis naturalmente toleráveis, o que provoca a retenção exagerada de calor e resulta no desequilíbrio climático da Terra. Segundo relatórios emitidos pelo Painel Intergovernamental de Mudanças Climáticas (em inglês, International Panel on Climate Change - IPCC) ${ }^{3}$ da ONU, o recrudescimento do efeito estufa causado pela ação humana provoca o aquecimento global, cujas principais consequências atualmente observadas vão desde a elevação gradativa da temperatura média terrestre até o aumento da ocorrência de catástrofes meteorológicas.

Com o crescimento exponencial das emissões de GEE e o incremento das concentrações destes gases na camada atmosférica o cenário pode ser ainda mais tenebroso. De acordo com as previsões do IPCC, se não forem tomadas providências para atenuar os níveis de GEE na atmosfera, haverá escassez de água potável, elevação dos níveis dos oceanos, extinção de espécies de animais e plantas e desequilíbrio do clima em diversas regiões do planeta. Essa onda de pessimismo incentivou a convergência de esforços e a adoção de medidas de combate à degradação desenfreada pelas autoridades internacionais.

Só a partir destas constatações é que as políticas de preservação ambiental baseadas no desenvolvimento sustentável entraram na pauta da agenda global.

\footnotetext{
${ }^{2}$ Disponível em www.mct.gov.br (acesso em 30.10.2011)

${ }^{3}$ Disponível em http://www.ipcc.ch/ (acesso em 27.10.2011)
} 
A primeira reação nesse sentido foi a criação do IPCC , em 1988, com o objetivo de se reunir vários cientistas e especialistas de diversas nacionalidades para estudar e discutir os impactos da atuação humana no meio ambiente, formalizando suas conclusões em relatórios que serviriam de base para a adoção de medidas de combate aos principais problemas ambientais.

Um marco na política de defesa do meio ambiente foi a realização da Conferência Rio-92, ocasião na qual foi instituída a Convenção Quadro das Nações Unidas sobre Mudança Climáticas (UNFCCC, sigla em inglês). A partir da adoção da Convenção Quadro, os países signatários da mesma vêm se reunindo anualmente nas chamadas Conferências das Partes (COP), com o intuito de encontrar soluções para o problema do aquecimento global e discutir propostas de ações concretas para mitigar as emissões desordenadas de GEE na atmosfera.

Este movimento de integração multilateral na busca do combate ao aquecimento global culminou na assinatura do Protocolo de Quioto, durante a realização da Terceira Conferência das Partes realizada no Japão em 1997, que, além de impor metas de reduções de emissão de GEE para os países desenvolvidos participantes, estabeleceu a criação de programas de flexibilização de emissões para auxiliar os participantes a alcançarem seus compromissos.

Sem dúvidas, dentre os meios de flexibilização implementados pelo protocolo, o Mecanismo de Desenvolvimento Limpo (MDL) ganhou destaque no cenário econômico mundial por caracterizar como um instrumento que conjuga interesses de países desenvolvidos e de países em desenvolvimento participantes do protocolo.

Em síntese, o MDL prevê a quantificação econômica de projetos de redução de emissão ou remoção de gases do efeito estufa com base no volume de gás carbônico efetivamente removido ou evitado de ser emitido, dando origem às Reduções Certificadas de Emissões (popularmente chamadas de "créditos de carbono") em favor dos empreendedores de tais projetos.

O grande avanço do modelo MDL consiste na possibilidade das RCEs serem objeto de alienação onerosa para empresas de países que possuam compromissos de redução ou limitação 
firmados através do Protocolo, o que as transforma em valiosos instrumentos de crédito do capitalismo global contemporâneo.

Concebe-se, assim, uma nova estrutura mercadológica, na qual as RCEs figuram como instrumento negociável, fomentando o desenvolvimento sustentável, através da conjugação da visão capitalista com os interesses de preservação ambiental.

A união destes dois temas como pontos fundamentais do estudo se faz necessária, uma vez que o estabelecimento de um regime regulatório para o mercado de créditos de carbono no Brasil pressupõe a definição da natureza jurídica das RCEs pela legislação pátria.

Até o momento, natureza jurídica das RCEs encontra-se pendente de definição, tanto no âmbito nacional quanto internacional de forma geral, não tendo sido sequer estabelecido o regime jurídico aplicável a tais créditos.

Apesar de todas as divergências teóricas e conceituais que norteiam o assunto, todos os especialistas compartilham de um entendimento em comum: o vazio jurídico não deve impedir que o mercado de carbono se desenvolva, sendo atualmente necessária a utilização de regimes análogos para garantir a operacionalização do setor, enquanto normas específicas não são editadas.

Nesse contexto, o objetivo precípuo da presente monografia, manifestado no próprio título do trabalho, assenta no estudo do tratamento jurídico das RCEs e as respectivas implicações na regulação do instituto no mercado de capitais.

Considerando as inúmeras controvérsias que pairam sobre o tema, é evidente a necessidade de um exame das diversas conceituações já propostas pela doutrina e jurisprudência para definir a natureza das RCEs e outros ativos ambientais equivalentes, sem, no entanto, ater-se a nenhum deles, visto que não constituirá o escopo deste estudo a defesa de nenhum dos conceitos

expostos. 
Superada essa questão, o objetivo do trabalho será voltado ao exame das principais características dos mercados formal e voluntário de carbono, traçando um paralelo entre as conclusões extraídas do estudo conceitual e as formas de organização de mercado de carbono já implementadas no exterior.

Ao final, serão estudados os modelos propostos por entidades especializadas para operacionalizar o mercado de carbono no Brasil. Este estudo comparativo terá por finalidade analisar a conveniência da regulamentação pertinente, ora em discussão no Congresso. Adicionalmente, será discutido o atual estágio de regulamentação dos ativos ambientais e do mercado de carbono nesta reta final da primeira fase do Protocolo de Quioto.

Por fim, para efeitos de padronização da nomenclatura ora utilizada, esclarece-se que, com base no sistema de equivalência em dióxido de carbono", o termo "carbono" é por vezes empregado no texto do presente trabalho para designar os demais gases do efeito estufa.

\section{EVOLUÇÃO HISTÓRICA DO DESENVOLVIMENTO SUSTENTÁVEL}

A origem das primeiras noções de desenvolvimento sustentável remonta ao século XVIII, a partir do surgimento das chamadas teorias econômicas clássicas, defendidas por autores expoentes como Adam Smith e Thomas Malthus, os quais em seus tratados já alertavam sobre os problemas decorrentes da relação entre o desenvolvimento econômico e o esgotamento dos recursos naturais.

${ }^{4}$ O sistema de equivalência em dióxido de carbono é uma medida internacionalmente aceita que expressa a quantidade de gases de efeito estufa (GEEs) em termos equivalentes da quantidade de dióxido de carbono (CO2). A equivalência permite comparar as emissões de diversos gases de efeito estufa baseado na quantidade de dióxido de carbono que teria o mesmo potencial de aquecimento global (GWP), medido em um período de tempo especificado (geralmente 100 anos). Fonte: Glossário de Termos relacionados a Mudanças Climáticas (Glossary of Climate Change Terms), disponível em http://www.epa.gov/climatechange/glossary.html (acesso em 04.11.2011) 
No entanto, durante um longo período da história contemporânea, o conceito de desenvolvimento sustentável foi deixado de lado em detrimento de políticas econômicas que se baseavam exclusivamente no crescimento tecnológico-industrial das sociedades como forma de atingir o mais alto nível de civilização. Nessa fase do capitalismo, predominava a corrente liberal, sendo que a abordagem do pensamento econômico excluía as vertentes sociais e ecológicas da compreensão de desenvolvimento. Acreditava-se que, no futuro, a escassez de recursos naturais seria suprida por tecnologias mais eficientes.

As décadas 60 e 70 marcaram o ressurgimento dos princípios do ecodesenvolvimento, impulsionados por uma onda mundial de conscientização ecológica iniciada nos países nórdicos e anglo-saxões. As autoridades internacionais deram conta que o modelo econômico industrial utilizado na época mostrava-se insustentável no longo prazo.

Varella (2003, p. 31) descreve esta etapa de transição como um momento em que "A comunidade internacional vai considerando, aos poucos, os dois temas como inseparáveis: o meio ambiente e o desenvolvimento constituem dois lados de uma mesma questão. (...) Esses conceitos de desenvolvimento revelam-se muito mais apropriados do que o conceito que se restringe unicamente à expansão comercial." e arremata afirmando que "A proteção do meio ambiente tornouse um elemento fundamental deste processo de desenvolvimento. Considera-se que toda a forma de desenvolvimento não sustentável contribui para a redução das liberdades das gerações futuras (...)”.

Com base nessas premissas históricas, será explorada a seguir a construção contemporânea do conceito de desenvolvimento sustentável a partir do estudo das propostas e soluções acordadas nas principais conferências e tratados internacionais referentes ao assunto, finalizando com uma exposição acerca da estrutura do Mecanismo de Desenvolvimento Limpo - MDL, que, a 
despeito de algumas críticas $^{5}$, constitui a principal ferramenta de promoção do ecodesenvolvimento na atualidade.

\subsection{A problemática ambiental contemporânea e o desenvolvimento sustentável}

É sabido que o mundo vive atualmente uma crise ambiental sem precedentes na história. Conforme já alertava Liebmann ${ }^{6}$ nos anos 70 , os problemas ambientais que hoje assolam a humanidade atingiram níveis que se aproximam de uma catástrofe ecológica, tendo como principais causas o crescimento demográfico aliado ao consumo desproporcional dos limitados recursos disponíveis na terra e a expansão desenfreada de atividades industriais.

Dentre os principais fenômenos que despertam a preocupação dos ambientalistas na atualidade figuram a poluição atmosférica, a contaminação de biomas por substâncias tóxicas, o desmatamento, a destruição da camada de ozônio pelos gases freon e o aquecimento global. Este último ganhou destaque nas décadas mais recentes pelo fato de estar relacionado a outros problemas ambientais (i.e. poluição atmosférica e desmatamento) e ainda por conta de seus primeiros impactos estarem sendo experimentados pelas atuais gerações.

Conforme sintetizado na introdução do presente trabalho, o aquecimento global é fenômeno proporcionado pela aceleração do efeito estufa, resultado da excessiva emissão de GEE à atmosfera, que, segundo o IPCC, acarreta os seguintes efeitos concretos na natureza: (i) aumento da acidez dos oceanos e consequente perda da vegetação marinha; (ii) degelo médio de 2,7\% por década no Ártico; (iii) deslocamento de espécies de seus habitat naturais; (iv) aumento da frequência de ondas de calor e tempestades; (v) maior retenção de vapor d'agua na atmosfera, o que potencializa o efeito estufa, agravando suas consequências.

5 "Infelizmente, o MDL é um mecanismo de mercado que se rege pela lógica do mesmo. Não se preocupa com a preservação ou proteção ambiental. Trata-se apenas da venda de um direito de poluir, colocado no mercado, pelos países em desenvolvimento, com vistas a conferir aos países industrializados uma redução nos custos de suas poluições." Barbosa e Oliveira (2006, pag. 128)

6 "Independentemente de sua orientação política, todos os países altamente industrializados da Terra estão a caminho da catástrofe ecológica."Libemann (1976, pag.57) 
Diante do cenário nefasto que se descortinava, a visão estritamente econômica do conceito de desenvolvimento foi sendo gradativamente superada, fazendo emergir um movimento internacional de incorporação de estratégias sócio-ambientais nas agendas políticas e jurídicas dos países e organismos transnacionais. Essa tendência dá origem aos primeiros regimes jurídicos internacionais voltados à harmonização do crescimento econômico e a preservação ambiental.

Especificamente no âmbito do combate ao aquecimento global, as ações tiveram início com a criação do IPCC em 1988, fruto do trabalho conjunto da ONU e da Organização Mundial de Meteorologia. O objetivo do painel possui caráter preventivo, pois consiste no estudo e análise dos impactos da atividade humana no meio ambiente, sendo que suas conclusões são formalizadas em relatórios que direcionam a adoção de medidas acautelatórias e corretivas.

Após dois anos da divulgação do primeiro relatório pelo IPCC, o qual sugeria a adoção de esforços conjuntos da comunidade internacional para solucionar a questão da emissão de GEE, foi formalizada a Convenção-Quadro das Nações Unidas sobre Mudanças Climáticas, na sede das Nações Unidas em Nova York, cujo conteúdo foi disponibilizado para adesão dos países interessados durante a Cúpula da Terra, realizada no Rio de Janeiro em junho de 1992, conhecida popularmente como Eco-92.

Uma curiosidade reside no fato do Brasil ter se tornado o primeiro país no mundo a assinar oficialmente à Convenção, evento este que ocorreu em 4 de junho de 1992 e marcou a aceitação do país ao termos e condições previstos naquele instrumento. Porém, a adesão do Brasil ao texto da CQNUMC, e, portanto, a manifestação da vontade de se obrigar à mesma, veio a ocorrer somente em fevereiro de 1994, com a sua ratificação através do Decreto Legislativo n. ${ }^{\circ} 1 / 94$.

Nos termos do Artigo 2 da Convenção ${ }^{7}$, o objetivo principal do documento e de quaisquer outros instrumentos jurídicos a ele relacionados é alcançar a estabilização das concentrações de gases de efeito estufa na atmosfera num nível que impeça uma interferência antrópica perigosa no sistema climático. Esse nível deverá ser alcançado num prazo suficiente que permita aos

7 Disponível no site www.mct.gov.br (acesso em 01.10.2011) 
ecossistemas adaptarem-se naturalmente à mudança do clima, que assegure que a produção de alimentos não seja afetada e que permita a continuidade do desenvolvimento econômico de maneira sustentável.

Portanto, trata-se do primeiro documento jurídico formal a reconhecer a responsabilidade da espécie humana pelo aumento das concentrações de GEE na atmosfera, evento este que afeta o equilíbrio climático do planeta. O texto atribui a maior parcela do encargo ambiental aos países desenvolvidos, com base em apontamentos históricos que demonstram que os níveis de emissões de GEE estão diretamente relacionados com os diferentes patamares de industrialização alcançados pelas nações.

A partir desses pressupostos, a Convenção propõe, como meta inicial, limitações não vinculantes de emissões antrópicas de GEE aos países desenvolvidos e demais nações constantes do Anexo $1^{8}$, no qual se inserem os países responsáveis pela maior parcela de emissões históricas. Por outro lado, os países não relacionados no Anexo 1 da Convenção, tidos como economias em ascensão, não sofreram quaisquer restrições de emissão, ao contrário, estão autorizadas a elevar em pequenas quantidades seus níveis de emissão para atender às demandas do desenvolvimento social e econômico.

Ainda no âmbito do texto da Convenção, merece destaque o seu Artigo 3 cuja redação estabelece orientações aos signatários para adoção de medidas unilaterais e plurilaterais de combate a mudança do clima, conforme definido naquele instrumento ${ }^{9}$. Como o próprio título do artigo prevê, o dispositivo consagra importantes princípios do direito ambiental internacional, quais sejam (i) o Princípio da Responsabilidade Solidária ainda que Diferenciada, (ii) o Princípio da

8 Os seguintes países integram o ANEXO I da Convenção: Alemanha, Austrália, Áustria, Belarus, Bélgica, Bulgária, Canadá, Comunidade Européia, Croácia, Dinamarca, Eslovaquia, Eslovênia, Espanha, Estados Unidos da América, Estônia, Federação Russa, Finlândia, França, Grécia, Hungria, Irlanda, Islândia, Itália, Japão, Letônia, Liechtenstein, Lituânia, Luxemburgo, Mônaco, Noruega, Nova Zelândia, Países Baixos, Polônia, Portugal, Reino Unido da GrãBretanha e Irlanda do Norte, República Tcheca, Romênia, Suécia, Suíça, Turquiae Ucrânia.

9 Artigo 1.Definições. Para os propósitos desta Convenção: (...) 2. "Mudança do clima" significa uma mudança de clima que possa ser direta ou indiretamente atribuída à atividade humana que altere a composição da atmosfera mundial e que se some àquela provocada pela variabilidade climática natural observada ao longo de períodos comparáveis." 
Precaução, (iii) o Princípio da Soberania, e o (iv) Ideal de Cooperação Internacional (Oliveira e Bocaiuva, 2009, pág. 469).

Tais princípios se manifestam de forma expressa em cada um dos itens que compõem o Artigo 3. Os itens 1 e 2 explicitam o Princípio da Responsabilidade Solidária ainda que Diferenciada ao estabelecer que as Partes devem proteger o sistema climático em benefício das gerações presentes e futuras da humanidade com base na equidade e em conformidade com suas responsabilidades comuns mas diferenciadas levando-se em plena consideração as necessidades específicas e circunstâncias especiais dos países em desenvolvimento. Já o item 3 prestigia o Princípio da Precaução quando define que as Partes devem adotar medidas de precaução para prever, evitar ou minimizar as causas da mudança do clima e mitigar seus efeitos negativos. O item 4 explicita o Princípio da Soberania ao prever que as políticas e medidas para proteger o sistema climático contra mudanças induzidas pelo homem devem ser adequadas às condições específicas de cada Parte e devem ser integradas aos programas nacionais de desenvolvimento. O Ideal de Cooperação por sua vez é tratado no item 5 do artigo, o qual dispõe que as Partes devem cooperar para promover um sistema econômico internacional favorável e aberto conducente com desenvolvimento econômico sustentáveis de todas as Partes.

Como se pode observar, a CQNUMC é considerado um marco no sentido de regular e promover ações voltadas a retomar o equilíbrio climático do planeta, através de um conjunto de princípios e regras genéricas e abrangentes. O caráter flexível do arcabouço normativo da Convenção demanda o detalhamento e a regulamentação do seu conteúdo através da edição de regramentos jurídicos específicos. A seguir serão abordados justamente os instrumentos complementares de fomento à Convenção, os quais são discutidos no âmbito das Conferências das Partes, órgão este que também será detalhado mais adiante. 


\subsection{O aquecimento global na agenda internacional}

\subsubsection{As Conferencias das Partes (COPs)}

Nos moldes estabelecidos por meio do Artigo 7 da Convenção, a Conferencia das Partes, ou COP como é conhecida, constitui órgão executivo máximo do tratado, composto por todos os países signatários do Protocolo de Quioto. Vale mencionar que os países que assinaram a Convenção, mas que não são partes do Protocolo, apenas participam das COPs como observadores, não possuindo o direito de votar e tomar decisões.

Anualmente, os representantes dos países participantes reúnem-se em encontros que são batizados com o nome da cidade onde são realizados, nos quais são discutidos os resultados da implementação da Convenção, bem como são colocados na ordem do dia para deliberação dos membros assuntos como a aplicação das diretrizes da CQNUMC, a regulamentação dos mecanismos previstos e o adimplemento das metas de redução.

Transcorridos 17 anos da entrada em vigor Convenção, foram realizadas até a presente data 16 Conferencias, sendo que a sua 17ạ edição está prevista para ocorrer entre os dias 28 de novembro e 9 de dezembro do ano corrente, na cidade sul africana da Durban.

Dentre as reuniões já concluídas, consideram-se aquelas que obtiveram os resultados mais significativos em termos de progresso no combate ao aquecimento global a COP 3 que culminou no estabelecimento de metas de redução de gases do efeito estufa para os principais países emissores, a partir da adoção do Protocolo Quioto; a COP 7, ocasião na qual foi celebrado o Acordo de Marrakesh, o qual regulamenta diversos pontos obscuros relacionados ao Protocolo, especialmente aspectos relacionados aos mecanismos de flexibilização, os quais serão esmiuçados no capítulo seguinte; e a COP 16, realizada em 2010 na cidade de Cancun, no México, que inovou com a criação do Green ClimateFund (Fundo Climático Verde), com o objetivo de financiar iniciativas desenvolvimento limpo nos países emergentes. 
O início do processo de negociação de metas e prazos específicos para redução de GEE pelos países desenvolvidos se deu com a realização da COP 1, sediada em Berlim de 28 de março a 7 de abril de 1995. A essa altura já se observava a necessidade de formalizar os compromissos de redução propostos durante a Eco92 e o resultado dessa conscientização geral foi a sugestão de elaboração de um protocolo que definisse claramente as responsabilidades de cada país signatário da Convenção. Nesse contexto, foi editado o Mandato de Berlim, através do qual foram estabelecidas as premissas para a adoção de um acordo mundial com vista a determinar as metas quantitativas de reduções de emissão de GEE, que viria a ser o Protocolo de Quioto.

Entre a COP 1 e a efetiva adoção do Protocolo de Quioto, ocorreu a segunda Conferencia das Partes COP 2, em julho de 1996. A decisão de maior relevância tomada na ocasião foi a possibilidade aberta aos países em desenvolvimento para solicitar à CQNUMC apoio financeiro para a implementação de programas de redução de emissões, com recursos provenientes do Fundo Global para o Meio Ambiente.

Só então no ano de 1997, durante a realização da terceira Conferência das Partes no Japão, foi adotado o Protocolo de Quioto. A COP 3 é considerada a principal conferência sobre mudanças climáticas já realizadas no âmbito da Convenção. Isto se deve ao fato de naquela ocasião ter sido elaborado o primeiro instrumento jurídico plurinacional a definir precisamente os compromissos de redução aplicáveis aos países desenvolvidos, conforme será analisado de forma aprofundada mais adiante.

Os dois encontros imediatamente posteriores à edição do Protocolo de Quioto centraram esforços na execução das medidas para garantir a operacionalização do acordo. Na COP 4, realizada em Buenos Aires, foram tratadas questões atinentes a mecanismos de transferência de tecnologia e financiamento de projetos, com a divulgação do Plano de Ação de Buenos Aires. No ano seguinte, a cidade de Bonn na Alemanha sediou a COP 5, quando então entraram em pauta as discussões sobre as definições de Uso da Terra e Mudança de Uso da Terra e Florestas (LULUCF, na sigla em inglês). 
A COP 6, realizada no ano de 2000, em Haia na Holanda, foi uma demonstração da dificuldade de se atingir um consenso em torno de um tema que transcende as fronteiras nacionais, como é o caso do efeito estufa. Durante a reunião surgiram os primeiros impasses acerca de assuntos relacionados aos MDL, mercado de carbono e comprometimento dos países em desenvolvimento. Os debates foram protagonizados especificamente entre União Europeia e os Estados Unidos, sendo que os empecilhos levaram à suspensão das negociações durante aquele ano e culminaram na saída do EUA do Protocolo. As reuniões só foram retomadas no ano seguinte, novamente na cidade de Bonn, sem que tenha havido nenhuma evolução nas negociações neste período.

O cenário de desentendimentos mudou durante a sétima reunião dos representantes dos países membros do Protocolo de Quito. A COP 7 desempenhou papel importantíssimo na adoção de regras operacionais para implementação dos dispositivos do protocolo por conta da celebração dos Acordos de Marrakesh. Estes importantes instrumentos definiram entre outros pontos, (i) a regulamentação dos mecanismos de flexibilização, incluindo a permissão para adoção de projetos unilaterais de MDL (sem a intervenção de um do Anexo I), (ii) a limitação do uso de créditos de carbono gerados a partir de projetos florestais do Mecanismo de Desenvolvimento Limpo, e (iii) a fungibilidade entre as unidades de crédito de carbono (AAU, RDEs e ERUs).

As demais Conferências das Partes que precederam o mais recente encontro realizado em dezembro passado, a COP 16, seguiram o cronograma anual de realização previsto na CQNUMC. No decorrer deste interregno não houve grandes avanços em relação ao que já havia sido implementado. O principal evento ocorrido no período foi a adesão da Rússia ao Protocolo de Quioto, em 2004, o que representou a sua 55a ratificação, resultando assim na entrada em vigor do documento, em 2005. Por outro lado, as iniciativas privadas e não governamentais nas esferas regionais representaram um grande passo no desenvolvimento dos mercados de carbono voluntários, que serão tratadas em capítulo próprio mais adiante.

A décima sexta e, até a presente data, última Conferencia das Partes, realizada entre os dias 29 de novembro e 11 de dezembro de 2010, foi palco de diversos acordos entre as nações 
membro, com destaque para a criação do Fundo Verde do Clima, responsável por administrar a ajuda financeira fornecida pelos países desenvolvidos aos países emergentes financiaria o desenvolvimento sustentável. Contudo, um ponto deixou a desejar durante as negociações mantidas na COP 16, foi a omissão em deliberar sobre novas medidas a serem adotadas em substituição aos dispositivos do Protocolo de Quito, o qual já encontra-seem fase final de vigência.

Traçado este panorama acerca das principais Conferências das Partes, o balanço final é de que as reuniões representaram a maneira mais efetiva e democrática de se discutir e desenvolver as ações previstas na Convenção, e, apesar das divergências, ao final foram atendidos os seus propósitos originalmente definidos. Tendo em vista que o primeiro ciclo de reduções estabelecido no Protocolo termina em 2012, a agenda mundial atualmente está focada nas negociações para elaboração de um novo tratado dispondo sobre novas metas vinculantes e no avanço das tratativas com os EUA para que o mesmo ratifique o documento. Dessa forma, a próxima Conferência prevista para ocorrer em novembro do ano corrente na cidade de Durban será a última oportunidade para se discutir o futuro do Protocolo de Quioto e os demais assuntos que integram a pauta ambiental internacional.

\subsubsection{O Protocolo de Quioto}

Conforme se depreende do histórico acima, a necessidade de se avançar com as metas não vinculantes previstas na CQNUMC foi manifestada de imediato desde a realização da primeira Conferência das Partes (COP 1), realizada na cidade de Berlim, no ano seguinte à edição da Convenção. Na ocasião, a pressão para adoção de um instrumento jurídico que formalizasse de forma cogente os compromissos firmados pelos signatários da Convenção resultou na assinatura do Mandato de Berlim, que desencadeou todo o processo de elaboração de um acordo global para definir os limites quantitativos de emissão de GEE, que viria a ser o Protocolo de Quioto.

Apesar de o processo ter se iniciado durante a COP 1, apenas no terceiro encontro das Partes (COP 3), realizado em Quioto, no Japão, é que a redação do Protocolo foi finalmente 
concluída e o documento, que levou o nome da cidade japonesa, foi oficialmente divulgado. Um ano após sua adoção, o Protocolo foi aberto a assinaturas das Partes.

O ponto alto do documento reside na definição de metas quantitativas de reduções de emissão de GEE para os países desenvolvidos. Calculadas levando-se em conta os níveis de emissões verificados em 1990, as metas foram estabelecidas sob a forma de compromissos vinculantes, sujeitos a sanções e penalidades em caso de descumprimento. Com base no já comentado princípio da Responsabilidade Comum ainda que Diferenciada, as obrigações de redução de emissões previstas no Protocolo de Quioto aplicam-se somente aos países signatários constates do Anexo I da CQNUMC (repetidas no Anexo B do Protocolo), em sua maioria economias desenvolvidas, onde historicamente se concentram as maiores fontes de emissão de GEE.

Nos termos do Artigo 3 do Protocolo, a meta geral de redução de emissões a ser alcançada de forma obrigatória pelos países membros do Anexo I corresponde a, no mínimo, 5,2\% em relação aos níveis verificados no ano de 1990, compromisso este que deve ser alcançado entre o período de 2008 a 2012, definido como a primeira fase de vigência do Protocolo.

O Anexo B, em mais uma clara expressão do princípio das Responsabilidades Comuns mas Diferenciadas no Protocolo, define as limitações quantificadas de emissões aplicáveis a cada uma das Partes obrigadas. Nele são listados os países participantes do Anexo I da CQNUMC e expressos os percentuais a serem atingidos por cada membro do anexo, de modo a distribuir a meta geral de redução com encargos diferenciados entre os signatários desenvolvidos.

Já antevendo as dificuldades de cumprimento das metas pelos países desenvolvidos, o Protocolo, em seu Artigo 2, elenca políticas e diretrizes a serem seguidas pelos países do Anexo I para fins de efetivamente reduzirem suas emissões. Em linhas gerais, as ações propostas incluem:

(i) Aumento da eficiência energética em setores relevantes da economia de cada país, através da pesquisa, promoção e desenvolvimento de: (a) sumidouros de GEE, (b) formas 
sustentáveis de agricultura e manejo florestal, (c) novas matrizes renováveis de energia, e (d) tecnologias mais eficientes no setor de transportes;

(ii) Oneração fiscal de atividades que não se enquadrem nos objetivos de redução de emissões de GEE, através da redução ou eliminação de benefícios fiscais e subsídios; e

(iii) Controle da emissão de metano por aterros sanitários mediante a sua recuperação e utilização na geração de energia.

Outra novidade do Protocolo com vistas a tornar mais factíveis as metas de redução de emissões consiste na previsão de mecanismos de flexibilização a serem utilizados pelos países desenvolvidos. São três os mecanismos de flexibilização regulados no Protocolo, quais sejam a Implementação Conjunta (Artigo 6), o Mecanismo de Desenvolvimento Limpo (Artigo 12) e o Comércio de Emissões (Artigo 17). Por possuírem estreita relação com os conceitos estudados no presente trabalho, tais institutos serão melhores detalhados no próximo subtítulo.

Os demais artigos do Protocolo dispõem sobre aspectos institucionais e regras de cunho jurídico que visam dar maior efetividade à implementação do documento. Destacam-se os dispositivos que disciplinam: (i) a estrutura e as competências dos órgãos complementares à Convenção e ao Protocolo; (ii) a cooperação técnica científica e financeira entre as Partes no sentido de mitigar os efeitos do aquecimento global; (iii) a obrigatoriedade de encaminhamento periódico pelas Partes de informações e relatórios a respeito das implicações internas da adoção do Protocolo; (iv) a possibilidade do estabelecimento de metas conjuntas de cumprimento dos compromissos de redução; (v) as sanções e penalidades no caso de descumprimento das normas do tratado; e (vi) disposições gerais, tais como foro de solução de controvérsias, forma e prazo para ratificações e condições de vigência. 
Nada obstante todo o esforço e empenho da comunidade internacional na elaboração de um tratado com normas vinculantes de reduções de emissões e ao mesmo tempo contemplando meios alternativos para viabilizar o cumprimento de tais regras, o Protocolo de Quioto foi e vem sendo alvo das mais diversas críticas, como as do sociólogo Michael Lowy ${ }^{10}$ que afirma que o protocolo "trata-se de um protocolo furado, com objetivo mínimos e, ainda assim, os Estados Unidos, país que mais polui, são contra a implementação".

Os resultados definitivos da adoção do instrumento só serão conhecidos em 31 de dezembro de 2011, quando se encerará o primeiro ciclo de compromisso previsto no acordo, mas independentemente das metas alcançadas uma certeza é indiscutível: a implementação do Protocolo representa um grande avanço na tendência do desenvolvimento sustentável no mundo.

\subsection{Os Mecanismos de Flexibilização}

Como visto anteriormente, apesar das críticas, o Protocolo de Quioto é considerado um marco no direito ambiental internacional, pois além de estabelecer compromissos vinculantes de redução de emissões por países poluidores (Anexo I), prevê ainda arranjos de mercado para tornar suas metas mais factíveis. Na definição do Conselho Empresarial Brasileiro para Desenvolvimento Sustentável - CEBDS $^{11}$, os mecanismos de flexibilização, como são chamados tais arranjos, são instrumentos comerciais implementados pelo Protocolo para viabilizar a execução de seus propósitos de redução de emissões e ao mesmo tempo assegurar uma transição economicamente viável para a adoção desse novo padrão.

A preocupação do documento em disponibilizar meios alternativos às Partes para facilitar o adimplemento das suas metas se justifica tendo em vista que um dos principais pontos de divergência durante as negociações mantidas para a elaboração do tratadoeram os elevados investimentos que as inciativas internas de redução de emissão demandariam, o que colocava em

\footnotetext{
${ }^{10}$ Fonte: Fonte: Ag. Carta Maior, Maurício Thuswohl, Rio de Janeiro, 12/10/2005.

${ }^{11}$ Disponível em http://www.cebds.org.br/cebds/ (acesso em 06.10.2011)
} 
risco a adesão de diversos países. Neste sentido, ainda segundo o CEBDS, os mecanismos de flexibilização do Protocolo de Quioto abrem opções de escolha para que se consiga a melhor relação custo-benefício dos investimentos necessários à adaptação dos países aos novos padrões da economia de baixo carbono.

Conforme já foi mencionado alhures, são três os mecanismo de flexibilização introduzidos pelo protocolo, quais sejam a Implementação Conjunta, o Mecanismo de Desenvolvimento Limpo e o Comércio de Emissões. Cumpre destacar que tais mecanismos são formas auxiliares de os países do Anexo I alcançarem metas e, portanto, não podem ser utilizados como o único meio para cumprimento dos compromissos, devem ter caráter adicional às medidas internas adotadas pelas Partes.

Ponto fundamental para compreensão dos mecanismos de flexibilização consiste no estudo do Acordo de Marraqueche. O referido instrumento, formalizado durante a sétima Conferência das Partes (COP 7), realizada em no Marrocos, é composto de 36 decisões, as quais compilam princípios, natureza, escopo, modalidades e procedimentos dos mecanismos de flexibilização. Em síntese, o Acordo estabelece regras operacionais para os mecanismos de flexibilização, regulamentando, de forma geral, os seguintes pontos: (i) diretrizes para a implementação dos mecanismos; (ii) modalidades e procedimentos para execução dos mecanismos; e (iii) capacitação nos países em desenvolvimento (Partes não-Anexo I).

Analisados os aspectos gerais concernentes aos mecanismos de flexibilização, passemos ao cotejo das definições e características específicas de cada modelo, com especial atenção ao Mecanismo de Desenvolvimento Limpo e ao Comércio de Emissões, que constituem conceitos básicos para o desenvolvimento do tema objeto da presente.

\subsubsection{Implementação Conjunta}

O mecanismo conhecido como Implementação Conjunta (Joint Implementation, em inglês), definido no Artigo 6 do Protocolo de Quioto, permite que um país com compromisso de redução 
ou limite de emissão nos termos Protocolo (parte integrante do Anexo B) obtenha Unidades de Redução de Emissões (ERUs) gerados por meio de projetos ou atividades de redução de emissões e remoção de GEE da atmosfera implementados em território de outro país do Anexo B, quando essas iniciativas são articulados conjuntamente entre tais países.

De acordo o UNFCCC ${ }^{12}$ a adoção do mecanismo de implementação conjunta oferece aos países do Anexo B um meio flexível e economicamente eficiente de cumprimento de parte dos seus compromissos no âmbito do Protocolo, uma vez que as Partes que participam conjuntamente dos projetos podem negociar as respectivas Unidades de Redução de Emissões entre si e contabilizá-las para efeitos de alcance de suas metas. Merece destaque ainda os benefícios decorrentes do ingresso de investimentos estrangeiros e transferência de tecnologia aos países hospedeiros promovidos pela adoção deste mecanismo.

Para que os países com metas previstas no Anexo B possam se beneficiar da implementação conjunta e estejam autorizados a transferir e/ou adquirir ERUs emitidas de acordo com tais projetos, é necessário que sejam observados os requisitos de elegibilidade previstos no parágrafo 21 das Diretrizes de Implementação Conjunta (JI Guidelines). A partir dos diferentes níveis de compliance destes requisitos de elegibilidade emergem dois diferentes processos de desenvolvimento de implementação conjunta.

Caso a Parte hospedeira cumpra todos os requisitos de elegibilidade, esta poderá adotar o processo simplificado batizado de "Track 1", através do qual a própria Parte hospedeira tem autonomia para verificar as reduções e remoções antrópicas de emissões de GEEs derivadas de projetos de IC e, com base nessa verificação, emitir a quantidade correspondente de ERUs.

Por outro lado, atendidos somente alguns dos requisitos de elegibilidade pela Parte hospedeira, o processo de verificação das reduções e remoções antrópicas de emissões de GEEs derivadas de projetos de IC deverá se sujeitar aos procedimentos do Comitê Supervisor da

\footnotetext{
${ }^{12}$ Disponível em http://unfccc.int/kyoto_protocol/mechanisms/joint implementation/items/1674.php (acesso em 05/10/2011)
} 
Implementação Conjunta (JISC, em inglês). Neste processo, denominado "Track 2", o JISC irá designar um órgão autônomo competente para autorizar a emissão e negociação de unidades de redução de emissão pelos países hospedeiros, após a verificação dos projetos de IC. Vale mencionar que a Parte hospedeira que observar todos os requisitos de elegibilidade pode optar por seguir um ou outro procedimento, já os hospedeiros que cumprirem com apenas parte dos requisitos estão adstritos ao Track 2 .

Portanto, apesar de tratar-se de uma possibilidade de flexibilização restrita aos países integrantes do Anexo B, a implementação conjunta congrega vários atrativos, tendo como principais benefícios (i) o estímulo de novas tecnologias e métodos de redução de emissões, (ii) o fato de possuir âmbito de aplicação irrestrito, e (iii) o fato de prestigiar atividades positivas de combate ao aquecimento global em detrimento da aplicação de penalidades. Demais disso, os especialistas acreditam que no futuro as ERUs serviram como uma válvula de escape para controlar os preços de créditos de carbono no âmbito dos esquemas cap-and-trade, conceitos estes que serão analisados no decorrer desta monografia.

\subsubsection{Comércio de Emissões}

Outro mecanismo de flexibilização não menos importante é Comércio de Emissões (Emission Trading - ET, em inglês), tratado no Artigo 17 do Protocolo de Quioto. De acordo com este mecanismo, as partes com metas instituídas no Anexo B podem estabelecer esquemas de comércio de emissões (Emission Trading Schemes, em inglês) no âmbito nacional ou regional como instrumento de política ambiental no sentido de reduzir os custos relacionados ao cumprimento dos seus limites de emissões de GEE. Como se vê, assim como a Implementação Conjunta, trata-se de um mecanismo de mercado restrito às Partes do Anexo $B$ do Protocolo.

O mecanismo baseia-se em um esquema no qual as Partes, inicialmente, estabelecem, na esfera nacional ou regional, permissões para emissões de GEE a seus jurisdicionados, expressos em $\mathrm{CO} 2$, definidos a partir das metas quantitativas instituídas no Protocolo de Quioto. Com base nesse 
modelo, as entidades abrangidas no esquema terão de limitar suas emissões de acordo com a permissão recebida, sujeitando-se a penalidade em caso de descumprimento. Conforme será ilustrado mais adiante, este regime conhecido como Cap and Trade Program constitui estrutura basilar no desenvolvimento de qualquer mercado de carbono.

Uma vez definidos estes limites, as unidades permissivas de emissões poderão ser comercializadas pelos seus detentores levando-se em conta os níveis de emissões verificados periodicamente. A operacionalização do mecanismo de comércio de emissões se dá a partir de premissa de que as Partes que alcançarem suas metas quantitativas de redução de emissões com sobras a partir de medidas adotadas internamente, poderão ceder onerosamente seus excedentes (Assigned Amount Units - AAU, em inglês) para outras Partes do Anexo B que, devido à insuficiência técnica ou econômica, não foram capazes de atingir suas metas de redução de emissões.

Cumpre destacar, que, ao contrário do que defendem alguns críticos do mecanismo, o Comércio de Emissões não constitui um mero artifício criado pelos países desenvolvidos para possibilitá-los adquirir "direitos de poluir", o que seria ineficaz do ponto de vista ambiental. Assim como os demais mecanismos de flexibilização, trata-se de um meio auxiliar, que só pode ser utilizado em parte para cumprimento das metas previstas no Protocolo, o restante deve obrigatoriamente ser alcançado através da efetiva redução nas emissões de GEE pelos países.

Justamente no intuito de combater a comercialização indiscriminada dos créditos de carbono pelas Partes através dos esquemas de comércio de emissões, o que fugiria aos propósitos dos mecanismos de flexibilização, foi estabelecido no Protocolo que cada Parte do Anexo B deve manter uma reserva de ERUs, CERs (RCEs), AAUs e/ou RMUs em seus registros nacionais, conhecida como "commitment period reserve". Adicionalmente, para evitar que os países do Anexo B fiquem impossibilitados de cumprir suas metas por conta do excesso de vendas de créditos de carbono, determinou-se um controle sobre os níveis dos referidos ativos ambientais nas reservas nacionais, os quais, por exemplo, em nenhum momento, podem atingir valores inferiores a $90 \%$ da quantidade originalmente atribuído àquele Parte. 
Além das AAUs, há a possibilidade de negociação de outras unidades de redução ao abrigo deste regime comercial, cada uma equivalente a uma tonelada de $\mathrm{CO} 2$, quais sejam:

(i) unidades de remoção (RMU) com base no uso da terra, mudança no uso da terra e reflorestamento;

(ii) unidades de redução de emissões (ERU) gerados por um projeto de implementação conjunta; e

(iii) reduções certificada de emissões (CER) gerados a partir de uma atividade de projeto de Mecanismo de Desenvolvimento. ${ }^{13}$

Mais uma vez, o que estimula os países do Anexo B a introduzir tal instrumento de mercado como forma de atingir suas metas de redução é o custo benefício que tal medida representa em relação aos investimentos necessários para o fomento de ações nacionais de redução de emissões. Atualmente existem diversos esquemas especiais de negociação de créditos de carbono, com destaque para o Esquema de Comércio da União Européia (European Union Emission Trading Scheme - EU ETS), que registra o maior volume de negociações no mundo. A regulamentação e as características dos principais esquemas de comércio de emissões em funcionamento serão abordados no capítulo 3 do presente trabalho.

13Disponível em http://unfccc.int/kyoto_protocol/mechanisms/emissions trading/items/2731.php (acesso em 06/10/2011) 


\subsubsection{O Mecanismo de Desenvolvimento Limpo (MDL)}

O Mecanismo de Desenvolvimento Limpo - MDL é um importante instrumento de flexibilização originado a partir de uma proposta apresentada por representantes brasileiros nas duas primeiras COPs, que sugeria a criação de um Fundo de Desenvolvimento Limpo, constituído através de recursos provenientes dos países do Anexo B, para financiamento de projetos ambientais de baixo carbono a serem implementados em países emergentes.

Em um primeiro momento a proposta brasileira não foi bem recepcionada pelos países do Anexo B. Porém após muita negociação, a ideia de criação de um Fundo de Desenvolvimento Limpo foi aprimorada e evoluiu até se chegar à atual estrutura do Mecanismo de Desenvolvimento Limpo. O conceito de fundo ambiental global apresentado pelo Brasil foi superado, mas a sugestão de investimentos em mecanismos sustentáveis nos países emergentes através do aporte de recursos de países do Anexo B para combater o aquecimento global foi mantida.

Segundo a CQNUMC ${ }^{14}$, o MDL baseia-se no duplo objetivo de "assistir as partes não incluídas no Anexo I para que atinjam o desenvolvimento sustentável e contribuam para o objetivo final da convenção e assistir as partes incluídas no Anexo I para que cumpram seus compromissos quantificados de emissões assumidos no artigo 3”․".

Neste cenário, o Brasil destaca-se como um potencial receptor de uma parcela significativa de projetos MDL por conta de suas condições naturais e econômicas. Os benefícios de hospedar tais projetos variam desde o recebimento de investimentos, sob o ponto de vista financeiro, até o acesso a tecnologias avançadas que permitirão o fomento de energias alternativas e, consequentemente, promoverão o desenvolvimento sustentável do país. Vale destacar que o primeiro projeto de MDL certificado pela ONU no mundo encontra-se no Brasil, trata-se do aterro sanitário de Nova Iguaçu, que negocia os créditos de carbono gerados a partir da atividade com adquirentes situados na Holanda, país com metas de redução nos termos do Anexo B.

\footnotetext{
${ }^{14}$ Idem
} 
O MDL encontra-se previsto no artigo 12 do Protocolo de Quioto, o qual, em linhas gerais, estabelece que as atividades que promovam a retirada da atmosfera ou a redução de emissão de GEE tem potencial para geração de certificados, denominados Reduções Certificadas de Emissões RCE (Certified Emission Reduction - CER), que poderão ser contabilizadas para fins de alcance de metas dos países do Anexo B. Quando implementadas individualmente por países não integrantes do Anexo B, caberá a estes negociarem as RCEs com os compromissados nos termos do Protocolo. Deste mecanismo decorre também a possibilidade das partes do Anexo B financiarem projetos de mitigação de emissões no território de países não - Anexo B e utilizar os resultados positivos obtidos para auxiliá-los no cumprimento de metas de redução de emissões.

Vale destacar que o dispositivo determina ainda os critérios que os projetos devem atender para que sejam validados como Mecanismo de Desenvolvimento Limpo, a saber: (i) voluntariedade; (ii) efetividade; e (iii) adicionalidade.

Primeiramente, tem-se que as partes envolvidas no projeto devem participar de forma voluntária, isto é, não são admitidas as atividades desenvolvidas em virtude de determinação legal, que afetem o caráter espontâneo do empreendimento.

Já o requisito da efetividade consiste na exigência de que o projeto contribua para o desenvolvimento sustentável dos países hospedeiros, ou seja, os benefícios por ele proporcionados devem ser reais, mensuráveis e relacionados à mitigação do aquecimento global no longo prazo. Deste modo, não basta que a atividade satisfaça as necessidades das presentes gerações, este deve garantir ainda a sustentabilidade no futuro.

Por fim é necessário que o projeto seja revestido de adicionalidade. De acordo com esta condição, as atividades serão elegíveis como MDL se as emissões antropogênicas de GEE se mostrarem menores elou se a remoção de GEE da atmosfera for superior do que normalmente ocorreria na ausência do projeto. 
Conforme visto, o Protocolo estabelece apenas uma definição geral do instituto, sua regulamentação se dá através do já estudado Acordo de Marrakesh, que veio a normatizar os detalhes operacionais aplicáveis ao MDL.

Como se pode observar na figura abaixo, um ponto negativo do MDL reside na complexidade dos procedimentos e metodologias relacionados à implementação dos projetos, os quais em muitos casos exigem o acompanhamento de uma assessoria especializada.

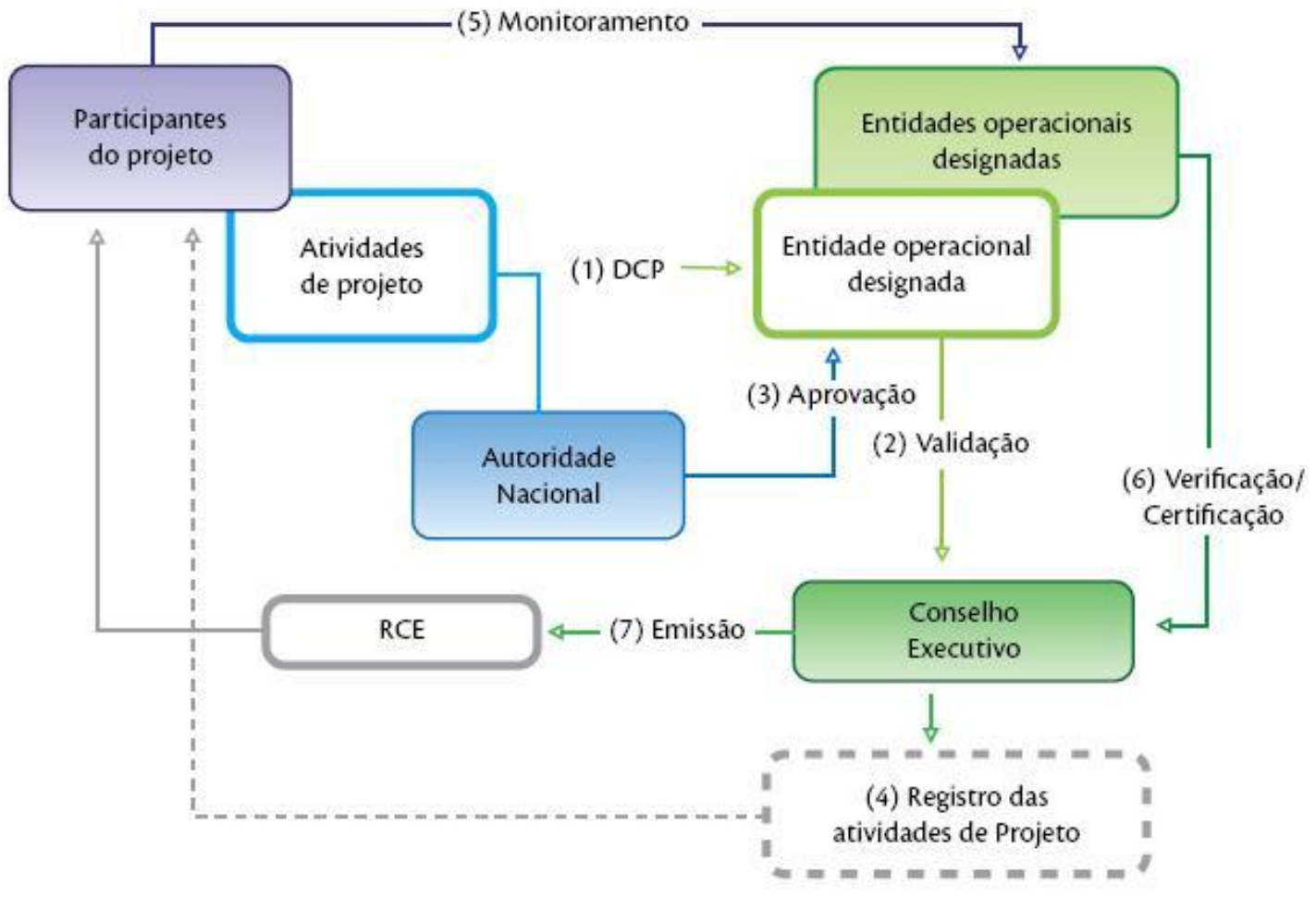

Figura 1 - Ciclo de um Projeto de $\mathrm{MDL}^{15}$

\footnotetext{
${ }^{15}$ Fonte: Manual de Capacitação sobre Mudança do Clima e Projetos deMecanismo de Desenvolvimento Limpo (MDL) - Brasília, DF: 2008
} 
Neste sentido, serão detalhadas a seguir as etapas processuais que envolvem desde a concepção à certificação dos projetos formatados no âmbito do Mecanismo de Desenvolvimento Limpo.

\subsubsection{Composição Institucional}

Antes de adentrar no estudo das etapas procedimentais relativas à concepção e certificação de projetos MDL, e a emissão de Reduções Certificadas de Emissões resultante deste processo, cumpre analisar a composição institucional do mecanismo. São três os principais entes envolvidos no processo, quais sejam, os próprios Participantes dos Projetos (Project Participants - PP, em inglês), o Conselho Executivo do MDL (Executive Board - EB, em inglês) e a Autoridade Nacional Designada (Designated National Authority - DNA, em inglês).

Os Participantes dos Projetos são normalmente empresas interessadas no desenvolvimento de atividades com potencial de gerar RCEs para eventualmente comercializá-las. Nada impede, contudo, que entes públicos, tais como governos locais e sociedades governamentais, participem, direta ou indiretamente, da implementação de projetos candidatos à certificação como MDL, os quais são formalmente denominados Atividades de Projeto (tradução livre de Project Activities, em inglês).

Dentro da hierarquia institucional, o Conselho Executivo do MDL figura como a instância máxima da ONU no que se refere ao registro, avaliação e validação de projetos. O Conselho é também a autoridade competente para emitir as correspondentes Reduções Certificadas de Emissões em favor de Participantes dos Projetos.

Na esfera local, as competências do Conselho Executivo do MDL são designadas a entidades indicadas pelo governo nacional para representar as Partes do Protocolo perante a ONU em assuntos relacionados ao MDL. No Brasil, este papel é exercido pela Comissão Interministerial para Mudanças Globais do Clima, órgão vinculado ao Ministério de Ciência e Tecnologia, instituído por 
meio do Decreto de 7 de julho de 1999, responsável, dentre outras atribuições, pelo monitoramento das Atividades de Projetos desenvolvidas no território nacional.

\subsubsection{Procedimento de Certificação de Projetos}

Conhecidas as principais instituições que compõem o processo de certificação das Atividades de Projeto, passemos à análise das etapas a serem percorridas pelos Participantes dos Projetos, que vão desde a sua concepção até a emissão de RCEs pelo Conselho Executivo.

O procedimento tem início com a estruturação do projeto, que se dá através da elaboração do Documento de Concepção do Projeto (Project Development Document - PDD, em inglês) pelos Participantes (PP). Tais documentos devem ser elaborados nos moldes das minutas fornecidas pelo Conselho Executivo de MDL, que variam de com o gênero de Atividade de Projeto, e conterão, dentre outras informações: (i) título do projeto e qualificação dos Participantes; (ii) descrição das atividades e localização onde serão implantada; (iii) cálculo estimado de redução de emissões; (iv) tecnologias a serem utilizadas; e (v) avaliação dos possíveis impactos ambientais; (vi) data inicial do projeto e duração do período de geração de créditos.

Uma vez elaborado o PDD, os Participantes do Projeto deverão submetê-loà apreciação de uma instituição independente acreditada pelo Conselho Executivo de MDL denominada Entidade Operacional Designada (EOD), responsável pela análise dos aspectos técnicos relacionados às Atividades de Projeto. Observados os requisitos do MDL, cabe à EOD validar o Documento de Concepção de Projeto, mediante a publicação do respectivo Relatório de Validação e o encaminhamento dos documentos à Autoridade Nacional Designada.

Seguindo o rito previsto no Acordo de Marrakesh, o PDD chega acompanhado do relatório favorável da Entidade Operacional Designada à Autoridade Nacional Designada para que seja declarada a aprovação ou rejeição do projeto como MDL. Conforme já mencionado, no Brasil esta atribuição compete à Comissão Interministerial para Mudanças Climáticas, que deve exercê-la com 
base nos critérios de sustentabilidade, capacitação tecnológica, voluntariedade e integração regional.

Caso haja o cumprimento de todas as condições necessárias para aceitação da Atividade de Projeto, o PDD é aprovado pelo AND e, em seguida, remetido ao Conselho Executivo de MDL para que sejam realizadas as etapas de verificação, certificação e emissão dos RCEs no âmbito internacional. Entre o registro e o inicio do procedimento de verificação do projeto, ocorre ainda o monitoramento das Atividades de Projeto, que tem por finalidade apurar os dados necessários para o cálculo das reduções de emissões de GEE.

A verificação e a certificação são procedimentos complementares ao monitoramento das emissões antrópicas de GEE que visam atestar formalmenteque os resultados previstos no PDD foram efetivamente alcançados.

A partir do momento que as Atividades de Projeto são certificadas, surge o direito dos Participantes do Projeto de requererem junto ao Conselho Executivo a emissão de RCEs equivalentes ao volume de redução de emissões de GEE verificado no decorrer do período de implementação do projeto de MDL.

Os RCEs distribuídos aos Participantes de Projetos na forma descrita nesta seção são registrados em uma conta de custódia em nome do beneficiário, administrada pelo Sistema de Registro do MDL, órgão este que também é responsável pelo acompanhamento da movimentação dos RCEs. Tão logo as RCEs são recebidas pelos Participantes, estas passam a integrar seus respectivos patrimônios, constituindo um ativo ambiental susceptível de alienação, cada vez mais valorizado, fazendo surgir assim mercados de negociação de RCEs e outros créditos de carbono cada dia mais robustos. A natureza jurídica desta nova espécie híbrida de ativo e a regulamentação dos mercados organizados destinados a comercialização destes produtos ambientais serão melhor estudadas no transcorrer do presente estudo. 


\section{DAS REDUÇÕES CERTIFICADAS DE EMISSÕES (RCES)}

Do mesmo modo que entre os mecanismos de flexibilização previstos no Protocolo merece destaque o MDL, por apresentar um cenário viável e promissor para o Brasil, no caso dos ativos ambientais, devem ser enfatizadas as Reduções Certificadas de Emissão - RCE, que, uma vez geradas a partir de projetos no âmbito do MDL, podem desempenhar um relevante papel no desenvolvimento da economia brasileira, e o mais importante, de forma sustentável.

No item 1.3.3 acima foram expostos os principais aspectos do regime jurídico internacional aplicável ao Mecanismo de Desenvolvimento Limpo e às RCEs, entretanto, trata-se de normatização recente e geral, que ainda demanda regras complementarese interpretação uniforme para alcançar o estágio máximo de eficácia. Nesse contexto, convém estudar a conceituação e natureza jurídica das RCEs, bem como as implicações legais da definição de tais noções, visto que a segurança jurídica no mercado de carbono representa um atrativo para potenciais investidores, e, consequentemente, fomentará ações de mitigação do efeito estufa e empreendimentos de baixo carbono.

A determinação de uma classificação jurídica das RCEs não só viabilizará sua regulamentação no mercado de capitais, como também permitirá sua contextualização sob o foco de diversos ramos incidentes do direito, tais como o direito tributário e o direito contábil. Ademias, de acordo com a Associação Brasileira de Empresas de Mercado de Carbono (Abemc) ${ }^{16}$, a ausência de um marco regulatório sobre o tema, estabelecendo as diretrizes para comercialização dos RCEs, compromete o futuro promissor do setor no Brasil.

\footnotetext{
${ }^{16}$ Disponível em http://www.abemc.com/br2/ (acesso em 26.09.2011)
} 


\subsection{Do Conceito de RCEs}

$\mathrm{O}$ artigo $1^{\circ}$, alínea $b$ do Anexo da Decisão 3/CMP. $1^{17}$ define as Reduções Certificadas de Emissões nos seguintes termos:

\footnotetext{
"Uma "redução certificada de emissão" ou "RCE" é uma unidade medida em conformidade com o Artigo 12 e os seus requisitos, bem como as disposições pertinentes destas modalidades e procedimentos, e é igual a uma tonelada métrica equivalente de dióxido de carbono, calculada com o uso dos potenciais de aquecimento global, definidos na Decisão 2/CP.3 ou conforme revisados subsequentemente de acordo com o Artigo 5."
}

Observa-se que as características expressas no artigo possuem caráter estritamente técnico, e, assim sendo, não fornecem subsídios necessários para o estabelecimento de uma definição jurídica das RCEs. A utilidade de tal conceito se limita às etapas de Verificação/Certificação das reduções de emissões de GEE e Expedição dos RCEs pelo Conselho Executivo do MDL, porém nada acrescenta no tocante aos aspectos jurídicos relacionados à comercialização destes bens ambientais.

Apesar da ausência de normas que estabeleçam a classificação jurídica da RCE tanto no âmbito internacional como à luz do direito pátrio, algumas considerações podem ser tecidas a partir do conceito técnico apresentado acima e das demais diretrizes previstas nos acordos internacionais em vigor.

É de se destacar o fato do atual regime jurídico das RCEs não determinar a sua existência física ou documental consubstanciada em título ou cártula, bastando o registro virtual das RCEs no Sistema de Registro do MDL para que seja comprovada sua existência. Neste ambiente eletrônico, vinculado ao Conselho Executivo do MDL, são também formalizadas as transferências dos créditos

\footnotetext{
${ }^{17}$ Disponível em http://cdm.unfccc.int/Reference/COPMOP/08a01.pdf (acesso em 13.09.2011)
} 
de carbono entre seus detentores, por meio de operações semelhantes às efetuadas por instituições bancárias.

Além deste registro mantido pelo Conselho Executivo do MDL, cabe a cada uma das Partes do Anexo I designar uma instituição para estabelecer e administrar o registro nacional de créditos de carbono de modo a assegurar a contabilização precisa da emissão, posse, transferência, aquisição, cancelamento e resgate de créditos de carbono. É facultado ainda a duas ou mais Partes consolidarem seus registros nacionais em um sistema integrado que permite maior interação entre os titulares de contas, desde que isso não comprometa o intercâmbio transparente e eficiente de dados entre os registros nacionais e internacionais.

No intuito de fiscalizar a validade das transações, inclusive a emissão, transferência e aquisição de créditos de carbono entre os registros nacional e internacional, o secretariado da CQNUMC instituiu o registro internacional de transações (ITL, sigla em inglês para International Transaction Log). Compete ao ITL, entre outras atribuições, registrar e tornar públicos os comprovantes de transação e a data e hora da conclusão de toda e qualquer transação realizada no âmbito do Protocolo de Quioto.

Em linha com exposto, percebe-se que a insuficiência do regime jurídico aplicável às RCEs em caracterizá-las do ponto de vista jurídico dificulta o trabalho dos doutrinadores em estabelecer um conceito prático para o instituto. Daí resultam noções pobres e imprecisas, que em linhas gerais definem as RCEs como certificados emitidos no âmbito do Sistema de Registro do MDL, comercializado através de meios eletrônicos criados a partir de regulamentos internacionais e domésticos, em geral mediante contratos privados.

\subsection{Da Natureza Jurídica das RCEs}

Conforme já exposto supra, é latente a necessidade de se definir a natureza jurídica das RCEs em face da omissão normativa que se instaurou nos regimes jurídicos nacional e internacional neste sentido. A regulação do tema constituiu um importante avanço na busca do pleno 
desenvolvimento do mercado de carbono no Brasil e no mundo, pois mitiga as incertezas e os riscos que rondam um setor em franca expansão.

Nesse tocante, vale destacar as lições de Filho e Sabbag (2009, pág. 7), segundo os quais seria prerrogativa exclusiva do Conselho Executivo do MDL regulamentar a natureza jurídica das RCEs, bem como a forma pela qual estas devem ser transacionadas globalmente, pois tais competências fogem à alçada jurisdicional dos estados membros. Aos países participantes do Protocolo seria permitido apenas estabelecer mercados internos de negociação de um "espelho" das RCEs, e determinar a natureza jurídica deste "espelho" no âmbito do mercado interno sob sua jurisdição. As transferências realizadas nos mercados internos envolvendo os "espelhos" das RCEs seriam refletidas no âmbito do Protocolo de Quioto, mediante a liquidação das operações correspondentes no Sistema de Registro do MDL.

Sob este cenário de incertezas, a natureza jurídica das RCEs ainda é objeto de diversas controvérsias, entretanto, já é possível identificar na doutrina e na legislação pátria cinco principais conceitos: (a) Bem Incorpóreo; (b) Derivativo; (c) Commodity; (d) Título ou Valor Mobiliário; e (e) Contrato de Prestação de Serviços. Partindo dessas definições manifestadas na doutrina, podemos classificar a natureza jurídica das RCEs de duas formas, de acordo com o nível de aprofundamento teórico e o grau de abrangência, dividindo-as em: latu sensu ou stricto sensu, conforme veremos a seguir.

Oportunamente, vale lembrar que o propósito deste capítulo do estudo se restringe a uma apresentação das diversas especulações surgidas a respeito do enquadramento jurídico das RCEs, sem qualquer pretensão de advogar a favor de nenhuma delas, mesmo porque grande parte das definições carece de embasamento legal, tendo origem em motivações econômicas e negociais.

\subsubsection{Da Natureza Jurídica Lato Sensu}

A princípio, a delimitação da natureza jurídica latu sensu das Reduções Certificadas de Emissões podem parecer de pouca valia do ponto de vista prático, por abordarconceitos 
teóricos abrangentes e superficiais. Porém, em se tratando de um tema repleto de incertezas e pouco consenso, torna-se de extremo relevo demarcar a classificação, ainda que lata, das RCEs para que se possam analisar os desdobramentos do tratamento legal de tais certificados nas esferas comercial e tributária.

Com efeito, Filho e Sabbag (2009, pág. 9) defendem, de momento, a adoção da classificação lato sensu da natureza jurídica das RECs, sob o pretexto de que o mercado de carbono ainda seria imaturo para receber uma definição mais detalhada do instrumento. Segundo os autores, " $a$ definição imediata e sem um aprofundamento teórico prévio acerca da natureza jurídica stricto sensu da RCE, dadas as grandes incertezas relacionadas ao tema, poderia até mesmo prejudicar a evolução e consolidação do Brasil como um importante pólo de geração e negociação de RCEs na América Latina, pois eventuais regras burocráticas e tributárias poderiam dificultar o pleno desenvolvimento deste mercado".

Passemos então ao breve cotejo daclassificação dos bens em incorpóreos e intangíveis, bem como as noções de ativo e derivativo, conceitos estes que são aprensentados na doutrina para definir a natureza jurídica latu sensu das RCEs.

\subsubsection{Bem Incorpóreo e Intangível}

De plano, cumpre esclarecer que apesar da reconhecida diferenciação doutrinária que se faz entre os conceitos de "coisa" e "bem abordada por Sister (2008, pág. 36) em seus estudos sobre mercado de carbono, reputo desnecessário entrar no mérito da questão, por entender que não há maiores dificuldades em identificar as RCEs como bens, posto que representam instrumentos dotados de valor econômico. Ademais, sendo uníssonas as opiniões no sentido de que os bens são uma espécie do gênero coisas, resta infrutífera tal caracterização.

Superado esse ponto, cabe agora adentrar ao estudo das variadas classificações aplicáveis aos bens, em especial quanto à sua corporificação e tangibilidade, visto que tais categorias são essenciais para se chegar a uma correta definição da natureza jurídica das RCEs. Embora de 
reconhecida importância, o Código Civil foi omisso em prever tais categorias de bens quando define, em cada uma das seções do seu Livro II da Parte Geral, os diferentes critérios de classificação dos bens. No silêncio da legislação pátria a respeito, coube à doutrina nacional desdobrar o tema.

A partir dos ensinamentos dos mais renomados civilistas, é possível concluir, em resumo, que os bens corpóreos são aqueles dotados de materialidade, cuja existência física pode ser facilmente percebida pelos sentidos humanos. Por outro lado, os bens incorpóreos, embora reconhecidos pela ordem jurídica, são desprovidos de existência material, não são tangíveis. É digno de nota o fato de que apesar dos bens incorpóreos terem caráter abstrato, não se discute sua existência jurídica, pois estes são capazes de agregar valor econômico independentemente da materialidade.

Tecidas estas considerações teóricas e tendo em mente o conceito de RCE construído na seção 2.1 acima, é forçoso caracterizá-las como bens intangíveis e incorpóreos, considerando que tais certificados constituem verdadeiros direitos representativos de reduções de emissão de GEE, passíveis de negociação no âmbito virtual dos registros eletrônicos, e, portanto, incorporam valor patrimonial ao seu respectivo detentor, apesar de não possuírem existência física.

Neste sentido, assevera Sister (2008, pág. 39)

“Assim, com base na classificação de bens sedimentada pela legislação e doutrina pátria, é possível afirmar que as RCEs, enquanto direitos sem existência tangível, todavia com valor econômico, enquadram-se com perfeição na acepção de bens intangíveis".

Corroborando do mesmo entendimento, Filho e Sabbag (2009, pág. 5) lecionam:

“Assim, da ainda embrionária doutrina jurídica pátria sobre o assunto, depreende-se que a RCE, se analisada sob a ótica do regime jurídico brasileiro, possuiria a natureza jurídica "lato sensu" de ativo incorpóreo ou intangível, pois, apesar de não possuir existência física ou cartular, ela representa um valor econômico que deve ser reconhecido pelo Direito". 
As demais categorias de bens trazidas no Código Civil falam por si só, de modo que dispensam esclarecimentos mais detalhados a respeito do enquadramento das RCEs. Assim, com base na classificação dos bens prevista no Código Civil, podemos definir as RCEs como bens $\underline{\text { móveis, }}$ infungíveis, indivisíveis e singulares.

Isso posto, será analisada a seguir a divergência criada em torno da classificação (latu sensu) das RCE como instrumentos financeiros, que se desdobra nos conceitos de ativo e derivativo. A definição das RCEs do ponto de vista econômico é elemento crucial no estudo do seu enquadramento jurídico, pois possui implicações diretas no regime comercial, tributário e contábil dos créditos de carbono.

\subsubsection{Ativo ou Derivativo?}

Antes de adentrarmos no estudo da natureza econômica dos créditos de carbono, se faz necessárioprecisar a abrangência dos conceitos de ativo e derivativo, comumente utilizados no mercado financeiro. Para tanto, recorreremos aos manuais de finanças e definições propostas por entidades reguladoras de mercados de capitais, procurando traçar um paralelo com o mundo jurídico.

Primeiramente, vale salientar que todos os conceitos conhecidos que buscam qualificar os derivativos resultam em definições amplas, vagas e elásticas, ao ponto do economista Frank Partnoy advertir que os derivativos são instrumentos notoriamente difíceis de categorizar, em parte por conta do significado ambíguo que o termo reproduz" (Partnoy e Skeel, 2007, 1.034).

Nada obstante, a U.S. Commodity Futures Trading Commission - órgão regulador do mercado futuro norte americanos - em síntese, define o conceito de derivativo comoo instrumento financeiro cujo valor altera-se em resposta à oscilação de outro ativo, seja uma taxa de juros específica, o preço de um instrumento financeiro, mercadoria, taxa de câmbio, índice de 
preços ou de taxas, avaliação ou índice de crédito, ou outra variável, que requer pouco ou nenhum investimento líquido inicial e é liquidado em data futura ${ }^{18}$.

Como se pode observar, o conceito de derivativo é desenvolvido exclusivamente a partir do método de apreçamento que lhe é peculiar. Essa conclusão nos permite entender a finalidade original de tais instrumentos, conhecida no mercado financeiro como hedge -expressão utilizada para designar a operação que visa reduzir ou eliminar o risco decorrente de oscilações no valor de mercado ou no fluxo de caixa de qualquer ativo, passivo ou transação futura, ou quaisquer outras variáveis às quais o agente econômico é exposto. Frise-se, contudo, que a característica do hedge por si só não é capaz posicionar ou não um bem financeiro no conceito de derivativo, tendo em vista que, atualmente, tais instrumentos vêm sendo utilizados com outras finalidades além do controle de riscos (hedge), quais sejam, a redução de custos, a especulação, a arbitragem e o planejamento tributário.

Face ao exposto supra, convém estabelecer um paralelo entre as características intrínsecas à noção de derivativo e a definição de RCEs, com vistas a verificar a adequação de tais conceitos. Dessa forma, segundo o entendimento de Souza e Miller (2003), o caráter acessório presente no conceito de derivativo é incompatível com a natureza da RCE, visto que o preço de negociação desta última não está atrelado a variáveis definidas por outros ativos subjacentes, como é da essência dos derivativos.

Compartilha deste entendimento o diretor da Comissão de Valores Mobiliários, Otávio Yazbek $^{19}$ :

\footnotetext{
${ }^{18}$ Derivative: A financial instrument, traded on or off an exchange, the price of which is directly dependent upon (i.e., "derived from") the value of one or more underlying securities, equity indices, debt instruments, commodities, other derivative instruments, or any agreed upon pricing index or arrangement (e.g., the movement over time of the Consumer Price Index or freight rates). Derivatives involve the trading of rights or obligations based on the underlying product, but do not directly transfer property. They are used to hedge risk or to exchange a floating rate of return for fixed rate of return. Derivatives include futures, options, and swaps. For example, futures contracts are derivatives of the physical contract and options on futures are derivatives of futures contracts. Fonte: CFTC Glossary, Disponível em http://www.cftc.gov/ConsumerProtection/EducationCenter/CFTCGlossary/glossary d (acesso em 23.09.2011)

${ }^{19}$ Voto proferido no âmbito doProcesso CVM n.o RJ 2009/6345
} 
"Se eles (créditos de carbono) são instrumentos "resgatáveis", no sentido de serem passíveis de transformação em um determinado tipo de vantagem econômica concreta, eles não são derivativos, mas os próprios ativos - inexiste ativo subjacente, sendo negociados os próprios ativos-objeto. (...) Entendo, desta maneira, que os créditos de carbono não são instrumentos derivativos".

No mais, discute-se ainda a presença ou não da finalidade de hedge no âmbito das RCEs, vez que, apesar de não constituir um conceito intrínseco a todos as espécies de derivativos, consiste em característica marcante destes instrumentos financeiros. Com efeito, não obstante alguns entendimentos em contrário, Souza e Miller $(2003)^{20}$ defendem que o gerenciamento de risco (hedge) não constitui elemento das RCEs, uma vez que as operações abrangendo estas espécies financeiras têm como fito apenas a utilização destes certificados como meio alternativo para cumprimento das obrigações assumidas sob o Protocolo de Quioto.

Contudo, caso as RCEs sejam objeto de contratos futuros ou de opções de compra, estas se amoldarão perfeitamente ao conceito de derivativo, e como tais, deverão ser negociadas em mercados de bolsa ou balcão.

Por outro lado, aqueles que repudiam a conceituação das RCEs como derivativos vislumbram um mero contrato de compra e venda nas operações que visam negociá-las. Dessa forma, os créditos de carbono seriam considerados simplesmente um ativo, aí entendido como um recurso do qual se espera que resultem benefícios econômicos futuros para o seu detentor ${ }^{21}$. A peculiaridade, no caso, seria o fato das RCEs consistirem em bens incorpóreos, o que faz delas um ativo intangível, assim como o fundo de comércio e a propriedade intelectual de uma empresa.

\footnotetext{
${ }^{20}$ Não se vislumbra como a preocupação com os gastos em tecnologia na adoção duma atividade de projeto, que levam o agente a optar pela compra de RCEs, possa constituir, verdadeiramente, um hedge, traduzindo-se, em verdade, em simples alternativa de mercado, custo-efetiva, à disposição dos agentes econômicos.

${ }^{21}$ Definição retirada do Pronunciamento técnico CPC-04 emitido pelo Comitê de Pronunciamentos Contábeis. Vide <www.cpc.org.br/pdf/CPC_04n.pdf> (acesso em 22.10.2011)
} 
Assim, como é da natureza dos ativos intangíveis, as RCEs não possuem relação monetária com qualquer elemento físico ou corpóreo, porém são identificáveis economicamente. Nas sábias palavras de Souza e Miller (2003, pág. 10), as RCEs representam um direito a um benefício futuro bem particular, que ele definem como a prerrogativa de "poluir" em conformidade com o Protocolo de Quioto.

Como veremos mais adiante, o estudo do caráter econômico das Reduções Certificadas de Emissões contribuirá para melhor compreensão das noções de natureza jurídica strictu sensu a serem abordadas, notadamente com relação classificação das RCEs como valores mobiliários.

\subsubsection{Da Natureza Jurídica Stricto Sensu}

Dentre as principais definições encontradas na doutrina para classificar os créditos de carbono, subsumem-se no plano stricto sensu os conceitos de commodity ambiental, títulos ou valores mobiliários e contrato de prestação de serviços, os quais serão tratados nesta seção. $\mathrm{Na}$ concepção de Filho e Sabbag (2009, pág. 4), a abordagem da natureza jurídica em grau stricto sensu seria desnecessária e inoportuna no atual estágio de desenvolvimento do setor, podendo até mesmo prejudicar a consolidação do instituto no Brasil ${ }^{22}$. Com a devida vênia ouso discordar de tal assertiva, pois entendo que quanto mais preciso enquadramento jurídico das RCEs no ordenamento brasileiro, mais segurança jurídica terão os investidores para auxiliar o desenvolvimento do mercado de carbono.

\footnotetext{
22 "Isto porque, a definição imediata e sem um aprofundamento teórico prévio acerca da natureza jurídica stricto sensu da RCE, dadas as grandes incertezas relacionadas ao tema, poderia até mesmo prejudicar a evolução e consolidação do Brasil como um importante pólo de geração e negociação de RCEs na América Latina, pois eventuais regras burocráticas e tributárias poderiam dificultar o pleno desenvolvimento deste mercado." Filho e Sabbag (2009, pág. 4)
} 


\subsubsection{Commodity Ambiental}

Desde a implementação do modelo MDL e suas Reduções Certificadas de Emissões, vem sendo aventada entre os estudiosos do Protocolo de Quioto a possibilidade de se conceber tais certificados como commodities, para fins de tratamento jurídico e financeiro. A própria CQNUMC refere-se aos créditos de carbono como commoditie sem seu website ${ }^{23}$.

No entanto, a mera utilização do termo na página virtual da CQNUMC não basta para estabelecer uma classificação definitiva das RCEs. Diante da indefinição quanto ao tema no âmbito do regime jurídico nacional e internacional, é indispensável uma análise pontual acerca da compatibilidade dos conceitos, estudo este que tem início no exame do vocábulo commodities sob o foco das ciências econômicas.

De acordo com os principais dicionários financeiros, commodity é o termo internacional utilizado para designar qualquer tipo de mercadoria em estado bruto ou com um grau muito pequeno de industrialização, dentre os quais se destacam produtos agrícolas (como café, soja e açúcar) e minérios (cobre, aço e ouro, entre outros). Nota-se que o conceito de commodity abarca os seguintes critérios de padronização: (i) negociabilidade, isto é, disponibilidade para comercialização; (ii) são tributáveis; (iii) esquema de transporte e estocagem apropriados; (iv) universalidade; e (v) liquidez.

Já um âmbito mais especifico, consideram-se commodities ambientais as mercadorias que obedecem os critérios de padronização e ainda são produzidas com base em condições sustentáveis, prestigiando a preservação ambiental. Outra importante característica atribuída às commodities em geral, é o fato de seu preço ser guiado pelo mercado, ou seja, varia de acordo com a disponibilidade e demanda do produto. (Neto, 2009. pág. 3)

A partir destas noções econômicas, permite-se concluir, juridicamente, que os bens sujeitos ao conceito de commodities são definidos com base apenas no seu gênero e espécie, podendo ser substituídas por outros bens da mesma natureza. Infere-se ainda o caráter de mercadoria das

\footnotetext{
${ }^{23}$ Disponível em www.unfccc.org (acesso em 21.10.2011)
} 
commodities, o que pressupõe sua existência física. Assim, deduz-se que as commodities são classificadas necessariamente como bens corpóreos/tangíveis e fungíveis.

Para Sister (2008, pág. 41), as ponderações feitas até aqui acerca das características das commodities já afastariam a possibilidade de enquadramento das RCEs no conceito. Segundo o autor, as RCEs mantêm um estreito grau de dependência em relação aos projetos de MDL que lhes deram origem mesmo apos sua emissão pelo Conselho Executivo, de modo que os certificados teriam, portanto, natureza infungível. Como se não bastasse, lembra o autor que os créditos de carbono, por consistirem em direitos sem existência material, são definidos como bens intangíveis, o que impossibilita ainda mais sua classificação como commodities ${ }^{24}$.

Nessa mesma esteira, outros renomados estudiosos do assunto como Souza (2008), Almeida (2005) e Neto (2009) defendem a posição de que o enquadramento das RCEs como commoditiesnão seria o mais adequado, pois, na hipótese, não estariam atendidos os requisitos de fungibilidade de intangibilidade, afetos ao conceito de commodities. Senão vejamos o que diz Neto (2009, pág. 3):

“Os CERs (leia-se RCEs), no entanto, não poderiam ser dissociados dos projetos que os geram. Dessa forma, não possuem a necessária fungibilidade, que caracteriza o próprio mercado de commodities."

Por tudo quanto fora exposto nesta seção, percebe-se que aqueles que defendem a caracterização das RCEs como commodities, o fazem sem nenhum embasamento jurídico, e não é

\footnotetext{
24 “Desse modo, e por haver um inerente grau de dependencia entre as RCEs e os projetos de MDL que as geraram nao me parece aceitavel que tais instrumentospossam ser tratados como bens de natureza infungivel. Nao fosse o suficiente, eh preciso lembrar que as RCEs, como direitos sem existencia material mas passiveis de negociacao, classificacam-se como bens de natureza incorporea ou intangivel. Com efeito, nao obstante alguns estudiosos do tema defendam a caraterizacao das RCEs como commodities - ou mesmo commodities ambientais - parece-me claro que faltam a tais instrumentos os elementos essenciais necessários a sua caracterização como tal." Mercado de Carbono e Protocolo de Quioto....
} 
por outro motivo que a atribuição da natureza jurídica de commodity aos créditos de carbono é tão questionada pela maioria esmagadora da doutrina.

\subsubsection{Título ou Valor Mobiliário}

Em meio às discussões travadas na doutrina acerca da correta classificação das RCEs sob o prisma jurídico, a maior parte das atenções voltam-se ao exame da inserção dos créditos de carbono no conceito de títulos e valores mobiliários.

Porém, antes de mergulhar no estudo da conceituação das RCEs como títulos ou valores mobiliários, é preciso elucidar as questões polêmicas relacionadas à delimitação dos termos título mobiliário e valor mobiliário. Embora as duas espécies de instrumentos financeiros tenham cada uma suas peculiaridades, o que conduz alguns autores a analisar a classificação da RCE sob dois diferentes focos, entendo que, para fins de enquadramento jurídico as mesmas devem ser consideradas como um só conceito amplo, pois pertencem à mesma natureza jurídica. Dessa forma consideraremos aqui a classificação lata dos valores mobiliários, na qual também se inseremos títulos mobiliários.

De modo geral, a conceituação dos valores mobiliários é delimitada no artigo 2 o da Lei 6.385 de 7 de setembro de 1976, cuja redação original elencava os títulos de investimento que se enquadram na categoria, da seguinte forma:

Art. 2‥ São valores mobiliários sujeitos ao regime desta Lei:

I - as ações, partes beneficiárias e debêntures, os cupões desses títulos e os bônus de subscrição;

II - os certificados de depósito de valores mobiliários;

III - outros títulos criados ou emitidos pelas sociedades anônimas, a critério do Conselho Monetário Nacional. 
Percebe-se assim que o legislador brasileiro optou pela sistemática de enumerar os instrumentos que pertencem à categoria de valores mobiliários, sem, contudo, estabelecer um conceito aplicável à espécie. Mais uma vez coube à doutrina especializada delimitar a classificação de valores mobiliários. Valemo-nos da brilhante lição de Mattos Filho (1984, pg. 32):

“Em conclusão e para efeito do mercado de capitais, valor mobiliário é o investimento oferecido ao público, sobre o qual o investidor não tem controle direto, cuja aplicação é feita em dinheiro, bens ou serviço, na expectativa de lucro, não sendo necessária a emissão do título para a materialização da relação obrigacional. O investimento é feito ou a nível associativo, a título de empréstimos, ou como aplicação especulativa pura."

Vale notar que o dispositivo sofreu profunda alteração com o advento da Lei n.o 10.303, de 31 de outubro de 2001, a qual acrescentou diversos incisos ao artigo, ampliando significativamente o rol de instrumentos abrigados pela definição de valores mobiliários. Com a nova redação, a lei que dispõe sobre o mercado de valores mobiliários e cria a Comissão de Valores Mobiliários passou a considerar sob tal rubrica os seguintes títulos:

(i) as ações, debêntures e bônus de subscrição;

(ii) os cupons, direitos, recibos de subscrição e certificados de desdobramento relativos aos valores mobiliários;

(iii) os certificados de depósito de valores mobiliários;

(iv) as cédulas de debêntures;

(v) as cotas de fundos de investimento em valores mobiliários ou de clubes de investimento em quaisquer ativos;

(vi) as notas comerciais; 
(vii) os contratos futuros, de opções e outros derivativos, cujos ativos subjacentes sejam valores mobiliários;

(viii) outros contratos derivativos, independentemente dos ativos subjacentes; e

(ix) quando ofertados publicamente, quaisquer outros títulos ou contratos de investimento coletivo, que gerem direito de participação, de parceria ou de remuneração, inclusive resultante de prestação de serviços, cujos rendimentos advêm do esforço do empreendedor ou de terceiros.

A respeito do tema, Carvalhosa e Eizirik (2009, pág. 481) ressaltam que, apesar de trazer novos incisos, a alteração legislativa mencionada acima limitou o conceito de valores mobiliários, por suprimir a possibilidade originalmente prevista no inciso III do artigo 2 o da referida lei, que dispunha a possibilidade do Conselho Monetário Nacional - CMN, a seu exclusivo critério, considerar como valores mobiliários outros títulos emitidos por sociedades anônimas. Neste sentido, segundo os renomados autores, o dispositivo passou a ter caráter exaustivo:

“Em sua redação original, o art. 2ํㅡ, em seu inciso III, em norma de duvidosa legitimidade, dispunha que o Conselho Monetário Nacional poderia, a seu critério, entender como valores mobiliários outros títulos emitidos por sociedades anônimas, além das ações, partes beneficiárias, debêntures, os cupons de tais títulos e os bônus de subscrição. Com a nova redação dada ao art. 2으, não mais existe a possibilidade de ser aumentado o elenco de valores mobiliários, seja pelo CMN, seja pela CVM. Dado o caráter flexível do conceito "títulos e contratos de investimento coletivo", presume-se que o legislador entendeu que não mais será necessária a ampliação do rol de ativos tidos como valores mobiliários, por meio da edição de normas regulamentares. Assim, o elenco de valores mobiliários previstos no art. 2 o da Lei $n \cong$ 6.385/76, em sua nova redação, passa a ser exaustivo e não mais exemplificativo." 
Desse modo, não mais se vislumbra a permissão para criação de novas espécies de valores mobiliários se não pela alteração do conteúdo do artigo 2o da Lei no 6.385/76 ou mediante a edição de novas leis. Em que se pese tal entendimento, nada impede que a CVM ou as cortes brasileiras venham reconhecer o enquadramento de novos tipos financeiros em um dos amplos conceitos definidos no citado artigo.

Especificamente com relação às RCEs, essa possibilidade de caracterização se debruça sobre os incisos VIII e IX, que tratam, respectivamente, da figura dos derivativos e dos contratos de investimento coletivo. De plano, a primeira hipótese esbarra na dificuldade de se compatibilizar as características dos créditos de carbono à noção de derivativo, conforme já constatado no item 2.2.1.2, quando foi estudada a natureza jurídica lato sensu das RCEs. Por sua vez, a inclusão das RCEs no conceito de contratos de investimento coletivo suscita maiores embates doutrinários devido à novidade do assunto.

Para grande maioria dos autores, dentre os quais Carvalhosa (2002, pág. 472$)^{25}$, a figura do contrato de investimento coletivo, inserida no artigo 2o da Lei 6.385/76 através do inciso IX, constitui uma adaptação do conceito norte americano de security, que de acordo com o Securities Act de 1993 é definido como qualquer espécie de título de investimento em dinheiro ou em bens suscetíveis de avaliação monetária, realizado por investidor em decorrência de uma oferta pública, com vistas ao fornecimento de capital de risco a um empreendimento, em que o investidor não tem ingerência direta, mas do qual espera obter lucro ou qualquer outra forma de benefício futuro. $^{26}$

\footnotetext{
25 “A Lei n. 10.198/2001 constitui importante marco no direito sobre mercado de capitais, ao conferir uma concepção abrangente aos valores mobiliários, por meio da adaptação do conceito de security do direito norte-americano, tal como entendido pela jurisprudência dos tribunais. A Lei n. 10.303/2001 sistematiza o elenco de valores mobiliários, nele incorporando o conceito mais amplo já contido na Lei $\mathrm{n}$. 10.198/2001, de títulos ou contratos de investimento coletivo, além de incluir os chamados derivativos em seu escopo" (Carvalhosa, 2002, p. 472).

${ }^{26}$ "The term 'security' means any note, stock, treasury stock, security future, bond, debenture, evidence of indebtedness, certificate of interest or participation in any profit-sharing agreement, collateral-trust certificate, preorganization certificate or subscription, transferable share, investment contract, voting-trust certificate, certificate of deposit for a security, fractional undivided interest in oil, gas, or other mineral rights, any put, call, straddle, option, or privilege on any security, certificate of deposit, or group or index of securities (including any interest therein or
} 
Com base nessas premissas, os autores buscam traçar um paralelo entre as caraterísticas das RCEs e o conceito de contrato de investimento coletivo importado do direito anglo-saxão, no intuito de verificar se as noções se adequam.

O primeiro ponto que se revela dissonante reside no fato de que os créditos de carbono não representam um "título de investimento em dinheiro ou em bens suscetíveis de avaliação monetária, realizado por investidor em decorrência de uma oferta pública", como sugere o conceito de securities, visto que, de acordo com Sister (2008, pág. 49), as RCEs importam em simples reconhecimento de que houve redução de determinada quantidade de emissão de GEE em decorrência de projeto de MDL.

Ademais, conforme ensinam Souza e Miller (2003), não há que se falar em "direito de participação, de parceria ou de remuneração" gerado a partir do título, como é da natureza dos contratos de investimento coletivos, vez que tal prerrogativa não se aplica ao detentor de Reduções Certificadas de Emissões.

Por fim, considerando que a Instrução CVM n. 270 de 23 de janeiro de 1998, restringe o direito de emitir títulos ou contratos de investimentos coletivos às sociedades constituídas sob a forma de companhias (S.A.), estariam excluídas deste conceito as RCEs, as quais são emitidas pelo Conselho Executivo do MDL.

Diante da relevância da questão, a Comissão de Valores Mobiliários - CVM, na qualidade de órgão regulador e fiscalizador do mercado financeiro, viu-se obrigada a emitir seu pronunciamento sobre o tema. O entendimento da autarquia se fundamenta no voto do seu diretor, Otávio Yazbek, proferido no âmbito do processo administrativo CVM n. RJ 2009/6346, no qual o julgador se propõe a expor considerações acerca da caracterização das Reduções Certificadas de Emissões e,

based on the value thereof), or any put, call, straddle, option, or privilege entered into on a national securities exchange relating to foreign currency, or, in general, any interest or instrument commonly known as a 'security', or any certificate of interest or participation in, temporary or interim certificate for, receipt for, guarantee of, or warrant or right to subscribe to or purchase, any of the foregoing". Securities Act 1993. Disponível em http://www.sec.gov/about/laws/sa33.pdf (acesso em 07.10.2011) 
ainda, identificar alguns efeitos de tal posição, notadamente no que concerne ao mercado de capitais.

Para fins do conteúdo ora estudado, merecem ser destacadas as seguintes conclusões extraídas do voto supracitado:

(i) os créditos de carbono não são instrumentos derivativos;

(ii) não há que se falar na caracterização da espécie como contrato de investimento coletivo, pois: (a) não há na espécie a manutenção de vínculo, em razão da aquisição de uma RCE, entre o adquirente desta e o agente econômico que implantou o projeto de MDL; e (b) as RCEs não se destinam a corporificar um investimento propriamente financeiro;

logo,

(iii) as RCEs não são, hoje, passíveis de caracterização como valores mobiliários, não estando, desta maneira, sujeitas ao regime estabelecido pela Lei no 6.385/76 para tais instrumentos;

(iv) não há necessidade, ante o processo de emissão de créditos de carbono e a natureza dos títulos, de buscar tal caracterização por força de legislação superveniente;

(v) outros instrumentos eventualmente relacionados às RCEs, como certificados, instrumentos sintéticos ou derivativos, poderão vir a ser caracterizados como valores mobiliários, tendo em vista a sua natureza, aplicando-se a eles, nestes casos, os regimes estabelecidos na regulamentação em vigor;

(vi) os fundos de investimento são autorizados a adquirir RCEs, nos termos do art. 2ํ, inc. VIII, da Instrução CVM no 409/04, observado, como se tratam de ativos emitidos no exterior, o disposto nos § 5ㅇ e 8을 do mesmo dispositivo; e

(vii) o mercado brasileiro já dispõe de alguns mecanismos hábeis ao financiamento e estruturação de projetos destinados à emissão de créditos de carbono. 
O posicionamento da CVM a respeito do tema foi oficialmente formalizado durante a Reunião do Colegiado № 25, realizada em 7 de julho de 2009, quando então foi decidido, com base no voto do Diretor Otavio Yazbek, que seria inconveniente caracterizar os créditos de carbono como valores mobiliários por meio da edição de lei, tendo em vista que, ante a estrutura atual de emissão desses instrumentos, o regime jurídico a que estão submetidos os valores mobiliários seria desnecessário. O Colegiado ainda concluiu que alguns produtos derivados de créditos de carbono, a depender de suas características, poderão ser considerados valores mobiliários, ponderação esta que deverá ser feita caso a caso pela CVM. Cumpre ressaltar que tal entendimento foi tornado público mediante comunicado disponível na página virtual da autarquia.

Quase um ano após o seu pronunciamento, mais precisamente em 7 de maio de 2010, a entidade foi provocada a se manifestar novamente sobre o assunto, agora com enfoque na Lei 12.187 de 29.12.2009, que será elucidada mais adiante, a qual em seu artigo 9o prevê a operacionalização do Mercado Brasileiro de Reduções de Emissões, nos seguintes termos:

"O Mercado Brasileiro de Redução de Emissões - MBRE será operacionalizado em bolsas de mercadorias e futuros, bolsas de valores e entidades de balcão organizado, autorizadas pela Comissão de Valores Mobiliários - CVM, onde se dará a negociação de títulos mobiliários representativos de emissões de gases de efeito estufa evitadas certificadas"

A consulta ${ }^{27}$ cingia-se a uma reanalise do enquadramento dos créditos de carbono no conceito de valores mobiliários, por conta do disposto no conteúdo do referido artigo que se refere a "títulos mobiliários representativos de emissões de gases de efeito estufa evitadas certificadas". Apesar da Lei 12.187 ter trazido diversas inovações no campo das RCEs e do mercado de carbono, a CVM concluiu que o texto da norma não alterou a natureza ou a estrutura das RCEs,

\footnotetext{
${ }^{27}$ Processo Administrativo CVM n. SP 2010/0107
} 
motivo pelo qual permanecem inalteradas as conclusões a que chegou o Colegiado da CVM quanto à impossibilidade de caracterização deles como derivativos ou como contratos de investimento coletivo.

Desta feita, diante do atual cenário normativo e doutrinário exposto acima, resta evidenciada a inviabilidade de se enquadrar as RCEs no conceito de valores mobiliários. Para tanto, será imprescindível a promulgação de ato normativo determinando a classificação dos créditos de carbono como tal, e, consequentemente sujeitando-os à regulamentação da CVM e ao regime da Lei $\mathrm{n}$. ㅇ 6.385 .

Neste contexto, vale assinalar a atividade legislativa existente no Congresso brasileiro no sentido de enquadrar as RCEs no conceito de valor mobiliário. Trata-se do projeto de lei n.으 493/2007 - cujo conteúdo deriva do PL 3552/2004, de autoria de Eduardo Paes, arquivado por conta do término do período de legislatura - que ao dispor sobre a organização e regulação do mercado de Carbono na Bolsa de Valores do Rio de Janeiro define, em seu artigo 4으, a natureza jurídica das RCEs como valores mobiliários e confere à CVM as atribuições de regulação, fiscalização e sanção no âmbito do mercado de carbono ${ }^{28}$. O referido projeto já recebeu parecer favorável da Comissão de Meio Ambiente e Desenvolvimento Sustentável e no momento encontrase sob análise da Comissão de Finanças e Tributação.

\subsubsection{Contrato de Prestação de Serviços (Circular BACEN n.o 3.291/05)}

A classificação jurídica das Reduções Certificadas de Emissões como contrato de prestação de serviço é de pouca valia do ponto de vista doutrinário, pois de plano já salta aos olhos a dificuldade de se encontrar pontos de convergência entre o conceito de créditos de carbono e o instituto do direito civil. De todo modo, conforme salienta Neto (2009, pág. 9), a definição da

\footnotetext{
${ }^{28}$ Art. 4ㅇ - Enquanto título, as RCEs, possuem natureza jurídica de valor mobiliário para efeito de regulação, fiscalização e sanção por parte da Comissão de Valores Mobiliários - CVM, sujeitando-se portanto ao regime da Lei 6.385 de 07 de dezembro de 1976. Parágrafo Único - Após aprovação pela Comissão Interministerial de Mudança Global do Clima, a CVM fica responsável pelo registro e validação das entidades operacionais designadas.
} 
natureza jurídica das RCEs como prestação de serviço ganhou força em razão da Circular n. 3.291, emitida pelo Banco Central do Brasil em 8 de setembro de 2006, que atribui o código "Serviços Diversos - Créditos de Carbono 29/(NR) 45500" para a realização de operações de câmbio que envolvam créditos de carbono, in verbis:

"Serviços diversos - Créditos de Carbono 29/(NR) 45500. Observadas as disposições da Res. 3.265, quanto à legalidade da transação, fundamentação econômica e responsabilidades definidas na respectiva documentação, podem as operações ser cursadas diretamente junto aos bancos autorizados a operar no mercado de câmbio.

TÍTULO: 1 - Mercado de Câmbio CAPÍTULO: 8 - Codificação de Operações de Câmbio SEÇÃO: 2 Natureza de Operação SUBSEÇÃO: 10 - Serviços Diversos - Créditos de carbono Código 45500."

O principal alvo daqueles que criticam a atribuição da definição jurídica de prestação de serviços às RCEs é justamente a impossibilidade de enquadramento do instrumento no conceito de prestação de serviços, que de acordo com a melhor doutrina civilista compreenderia toda atividade lícita de serviço especializado, realizado com liberdade técnica, sem subordinação e mediante certa retribuição.

Assim, a partir do exame da própria concepção de prestação de serviço, percebe-se que a natureza das RCEs não guarda relação com a categoria, visto que o Banco Central deixou de observar os elementos essenciais para considerar tal enquadramento. Primeiramente, tem-se que para o adimplemento de uma prestação de serviço faz-se necessária uma obrigação de fazer, enquanto que no caso das operações com RCEs a obrigação é de dar alguma coisa, pois tratando-se os créditos de carbono de bens incorpóreos, prestam-se à cessão, consoante leciona Venosa (2006). Em segundo lugar, conforme assinala Camargo (2010, pág. 54): 
“(...) essa classificação não é cabível, pois a ideia de prestação de serviço se prolonga em um espaço específico de tempo e a RCE, por sua vez, tem na sua emissão um fato pontual, tornando-se imutável após isso, representando uma declaração de que um projeto específico evitou que fosse emitido ou realizou o sequestro de uma tonelada de CO2 e na atmosfera, não representando, portanto, uma obrigação de fazer ou a realização de um serviço a alguém."

Essa confusão criada em torno do conceito de prestação de serviços, entendo eu, decorre de uma interpretação equivocada da Circular BACEN 3.291/06, que não tinha a pretensão de estabelecer a natureza jurídica das RCEs, como sugerem alguns estudiosos, mas detinha-se tão somente a classificar o negócio jurídico que tem como objetivo a transação de titularidadede RCEs, para fins exclusivos de controle cambial e fiscal.

Face o exposto, constata-se não ser razoável a inserção das RCEs no conceito de prestação de serviços. Passemos então ao exame dos regimes jurídicos adotados no direito comparado para classificar os créditos de carbono.

\subsection{Classificação dos RCEs no direito comparado}

Até a presente data, não identificamos a existência de tratados internacionais que disponham sobre a classificação jurídica das Reduções Certificadas de Emissões, situação esta que cria incertezas com relação aos aspectos fiscais, comerciais e contábeis das negociações destes instrumentos.

Não obstante a ausência de regulamentação em nível global, constatamos que alguns países já adotaram uma definição acerca da natureza jurídica das RCEs em suas legislações locais, a saber: Chile, China, Argentina e Japão. 


\section{Chile}

O Chile é signatário tanto da CQNUMC como do Protocolo de Quioto, sendo que neste último figura como parte do Anexo II, o que lhe isenta de qualquer obrigação de redução de emissões. Assim como o Brasil, o Chile possui sistema de certificação de projetos de MDL bem organizado, contando com uma Autoridade Nacional Designada, denominada CONAMA.

Nesse contexto, o país tem reconhecido a natureza jurídica dos créditos de carbono como bens móveis, susceptíveis de apropriação e comercialização, amparados pelas garantias do direito de propriedade privado, que no país é considerado direito humano ${ }^{29}$. Esse regime limita a intervenção do estado na relação de domínio que os titulares exercem sobre das RCEs, assegurando liberdade negocial no mercado de carbono do país.

\section{China}

Também como país signatário do Protocolo de Quioto e da CQNUMC, porém não integrando o Anexo 1 destes instrumentos, a China não possui metas de redução de GEE. O país é o líder mundial no comércio de RCEs, contando atualmente com o maior número de projetos de MDL registrados perante o Conselho Executivo entre todas as nações do mundo.

Em razão do seu potencial de desenvolvimento de projetos de MDL e do elevado volume de RCE negociado, a China conta hoje com uma regulamentação quanto ao tratamento jurídico aplicável aos créditos de carbono, que os define como um recurso natural pertencente ao estado, o que se deve às raízes socialistas do país ${ }^{30}$.

\footnotetext{
${ }^{29}$ Revista de Derecho Administrativo Economicon. 14, pags. 95 - 104 (2005) Viñuela Hojas, Mauricio

30 The People's Republic of China (PRC): has stated that all land belongs to the State and that all CERs are natural resources which also belong to the State. TACIS, Clean Development Mechnism, Handbook for Armenia (2006)
} 
Argentina

A Argentina se encontra na mesma situação que Chile e China, sendo signatária do Protocolo e da CQNUMC embora não possua qualquer limitação de emissão de GEE por não constar no Anexo I daquele instrumento.

Com relação ao tema, determina o Código Civil Argentino que as Reduções Certificadas de Emissões poderão ser caracterizadas como frutos industriais ou civis decorrentes do projeto de MDL, e como tais, as RCEs pertenceriam ao idealizador do projeto que originou os créditos, caso não exista nenhuma disposição em contrário entre partes.

Japão

O Japão, por sua vez, além de ser signatário da CQNUMC e do Protocolo de Quioto, é parte integrante do Anexo I dos referidos instrumentos, pelo que possui compromisso de redução de emissões de aproximadamente 6\% (seis por cento) em relação aos níveis observados em 1990.

Considerado um dos principais poluentes do mundo, o Japão não possui condições geográficas nem potencial de desenvolvimento de mecanismos de flexibilização, de modo que a aquisição de créditos de carbono de outras nações corresponderá a uma vultosa parcela no atendimento das metas impostas ao país no âmbito do Protocolo.

Cientes da importância que a comercialização de RCEs representam para o país, as autoridades japonesas trataram de estabelecer o tratamento jurídico dispensado a tais certificados, admitindo-os como ativo intangível transferível eletronicamente, segundo determina a Lei de Políticas de Mudanças Climáticas (Climate Change Policy Law). 
Apenas a título de informação, vale mencionar que em Ghana, o direito conferido ao detentor de uma RCE é considerado vinculado ao local onde o projeto de MDL que lhe deu origem foi implementado, podendo inclusive ser objeto de registro no órgão equivalente ao Cartório de Registro de Imóveis daquele país.

A partir deste breve estudo comparado, constata-se que das principais classificações aventadas na doutrina pátria acerca das RCEs, apenas a noção de ativo intangível introduzida no direito japonês coaduna com o entendimento dos estudiosos nacionais. Observa-se adicionalmente, que a maior parte dos países ainda não editou legislação tratando da natureza jurídica dos créditos de carbono.

\section{REGULAMENTAÇÃO DO MERCADO DE CARBONO}

Concluída a perquirição acerca da estrutura do MDL e da classificação jurídica das Reduções Certificadas de Emissão, voltemo-nos ao estudo do principal efeito da introdução de tais conceitos na economia global e a sua respectiva regulamentação.

Como visto anteriormente, o MDL e as RCEs propiciam a integração entre partes constantes do Anexo 1 do Protocolo de Quioto e os países subdesenvolvidos incubadores de projetos sustentáveis, permitindo que os países compromissados atinjam suas metas de redução mediante a utilização de créditos de carbono originados em decorrência de tais projetos .

A partir desta dinâmica, é concebido um sistema de negociação de ativos ambientais, batizado de Mercado de Carbono, no qual as unidades de redução de emissões de GEE figuram como o principal bem comercializado e os países relacionados no Anexo 1 respondem pela demanda deste novo produto comercial, com o intuito de reduzir os custos incorridos no cumprimento de suas metas. 
Há que critique a implementação do mercado de carbono alegando que a sustentabilidade ambiental é utilizada como mero pretexto para se alcançar vantagens financeiras, sugerindo que o mercado de carbono envolveria apenas motivações capitalistas, sem ater-se a preocupações ambientais. Outros, por sua vez, entendem que o panorama internacional dominado por sociedades capitalistas, requer a adoção de soluções ambientais compatíveis com o atual cenário econômico, caso contrário, seria inviável o desenvolvimento sustentável.

A despeito destas discussões morais e éticas, verdade é que já existem diversos mercados em operação, e só o tempo dirá a que fins o mercado de carbono realmente se presta. Enquanto esta questão permanece como incógnita, cabe aqui examinar os aspectos jurídicos inerentes ao mercado.

\subsection{As Espécies de Mercado de Carbono}

Apesar de completos seis anos da entrada em vigor do Protocolo de Quioto e não obstante todo o interesse que gira em torno das negociações com créditos de carbono, o mercado de ativos ambientais decorrente do acordo ainda carece de regulamentação precisa no âmbito internacional.

As diretrizes gerais estabelecidas no Protocolo e nos acordos correlatos adotados no âmbito das COPs apenas tratam de forma superficial acerca dos esquemas de mercado resultantes dos mecanismos de flexibilização, sem prever regras concretas capazes de ordenar o funcionamento de um mercado de negociação de créditos de carbono diretamente vinculado aos órgãos institucionais da CQNUMC.

Por conta desse limbo normativo, o que se vê cada vez mais é a formação de regimes de negociação de créditos de carbono desvinculados do Protocolo de Quioto, nos quais os participantes não se sujeitam aos critérios, exigências e metas impostas aos países que ratificaram o referido tratado. Muito embora tenham surgido na esteira da CQNUMC, tais esquemas possuem 
normas próprias de funcionamento, definidas por meio de acordos regionais, geralmente dotados de regras menos rigorosas do que as estabelecidas no Protocolo.

Essas duas diferentes esferas de negociação de créditos de carbono permitem uma classificação dos regimes de mercado em duas espécies: o mercado de carbono formal e os regimes de negociação voluntários. Tal segregação leva em consideração a adesão ou não do esquema negocial aos preceitos do Protocolo.

\subsubsection{Mercado Formal de Carbono}

O Mercado Formal de Carbono é composto pelos regimes de negociação de créditos de carbono originados a partir da adoção dos mecanismos de flexibilização previstos no Protocolo de Quioto, a saber: a Implementação Conjunta, o Mecanismo de Desenvolvimento Limpo e o Comércio de Emissões, todos esmiuçados em capítulo próprio.

A iniciativa de implementar tal sistema tem como principal objetivo atender à demanda dos agentes públicos ou particulares que possuem metas de emissão de GEE sob o Protocolo e não são capazes de honrar seus compromissos ambientais através de ações internas sem que isso afete substancialmente a economia local ou a produção, conforme o caso. Assim, os produtos transacionados no mercado formal são, principalmente, as Unidades de Redução de Emissões (ERU, em inglês) e as Reduções Certificada de Emissões (CER, em inglês), instrumentos estes representativos de créditos e permissões de emissão de GEE gerados através da adoção de projetos de MDL e de Implementação Conjunta, respectivamente.

Com base nas diferentes formas de aquisição originária dos créditos de carbono, é possível distinguir as transações no mercado de carbono em duas diferentes categorias, aplicáveis tanto ao mercado formal, como no mercado voluntário. A primeira delas seria representada pelas allowance based transactions, negociações nas quais as unidades de carbono são comercializadas na forma de permissões de emissões de GEE. Num segundo plano teríamos as Project based transactions, que correspondem às operações que têm por objeto a negociação de unidades de 
redução de emissões, geradas por projetos sustentáveis, como, por exemplo, as transações envolvendo as próprias RCEs. No caso das permissões de emissão a aquisição se dá geralmente através da colocação direta no mercado de forma gratuita ou via leilões, promovidos por agentes de mercado. As unidades de redução de emissões, por sua vez, são originárias de Atividades de Projeto, cuja implementação resulte em redução de emissões ou remoção de GEE da atmosfera, devidamente verificada e certificada por autoridade especializada e competente, que no âmbito do Protocolo de Quioto, como vimos, trata-se do Conselho Executivo do MDL e seus órgãos subordinados.

Conforme abordado acima, o regime formal de negociação ainda não foi efetivamente implementado no ordenamento jurídico internacional, pelo que hoje não existe um esquema próprio e organizado de negociação de ativos ambientais mantido pelo Conselho Executivo do MDL e seus órgãos subordinados.

\subsubsection{Mercados Voluntários}

O mercado voluntário, a seu turno, é representado pelos regimes de negociação não incluídos no Protocolo, estabelecidos a partir da iniciativa dos governos locais, que, motivados pelo interesse geral da sociedade em garantir a sustentabilidade terrestre e mitigar as consequências danosas do efeito estufa, buscam atitudes mais afirmativas de proteção ambiental.

Por esta razão, os principais mercados voluntários existentes foram empreendidos em países que em tese teriam compromissos de redução de emissões nos termos do Protocolo, mas que pelo fato de não terem aderido ao acordo, não estão formalmente sujeitos às metas, e consequentemente, a pressão da sociedade por medidas sustentáveis é maior. Destacam-se neste contexto os esquemas de negociação voluntários implementados nos EUA e na Austrália.

O funcionamento dos mercados voluntários é baseado em regras próprias, geralmente mais flexíveis que as da CQNUMC, que também preveem compromissos de redução de emissões, 
porém, neste caso, as metas são regionais e nem sempre resultam em sanções por descumprimento.

Quanto aos produtos transacionados nestes mercados, não necessariamente são créditos de carbono advindos dos mecanismos de flexibilização do Protocolo. Os respectivos regulamentos estabelecem as permissões ou reduções de emissões passíveis de comercialização, que, em regra, devem ser verificadas e certificadas por empresas de auditoria especializadas, devidamente credenciadas.

Ainda no âmbito dos mercados voluntários, a doutrina sugere uma classificação mais aprofundada, a partir da vinculação ou não dos esquemas às regras do Protocolo. Assim, existiriam os mercados considerados Kyoto Compliance, que englobam os esquemas que guardam certa relação com as normas do Protocolo de Quito, como por exemplo o European Union Emission Trade System, que por possuir vinculação ao regime do Protocolo de Quioto, permite que os créditos de carbono ali negociados possam ser utilizados para atingir as metas impostas pelo tratado, e vice versa. Por outro lado, há também os mercados non-Kyoto compliance, que aplicam regras próprias e baseiam-se em compromissos de redução de emissões de GEE completamente independentes dos previstos no Protocolo, estes seriam mercados estritamente voluntários, como é o caso do Chicago Climate Exchange, principal esquema de negociação dos EUA, país este que sequer ratificou o Protocolo de Quioto.

Quase todos os mercados voluntários operam através do sistema cap and trade, cujo conceito reproduz a metodologia utilizada no Protocolo de Quioto. Segundo definição da Agência de Proteção do Meio Ambiente dos Estados Unidos (EPA) ${ }^{31}$, cap and trade é um mecanismo de mercado por meio do qual são estabelecidos limites de emissão de GEE a um determinado setor ou grupo, sendo que, com base nas metas de cada participante, são outorgadas permissões de emissões pela autoridade reguladora, existindo ainda a possibilidade dos participantes recorrerem a alternativas sustentáveis para obter permissões adicionais. A partir daí, permite-se que os

\footnotetext{
${ }^{31}$ Disponível no site <http://www.epa.gov/captrade/> (acesso em 27.10.2011)
} 
participantes transacionem suas permissões entre si, resultando em um ambiente de negociação que se torna o cerne do sistema.

\subsection{Estruturas de Mercados Voluntários Existentes}

Ultrapassada a abordagem superficial acerca da estrutura, classificação e funcionamento dos mercados de carbono, verifica-se que a tendência do setor é o crescimento cada vez maior dos mercados voluntário e a estagnação do sistema formal, justamente por conta da falta de regulamentação deste último, o que faz com que as empresas optem por negociar seus créditos de carbono através de esquemas voluntários, especialmente aqueles classificados como Kyoto Compliance.

Esta tendência é confirmada no relatório elaborado pelo Ecosystem Marketplace em parceria com a Bloomberg New Energy Finance ${ }^{32}$, onde se constata que o mercado voluntário atingiu em 2010 o volume recorde de 131 milhões de toneladas de dióxido de carbono equivalente (MtCO2e), aumentando seu valor estimado para US\$ 424 milhões, enquanto que o mercado global de carbono sofreu uma pequena retração pela primeira vez na sua história, reduzindo 1,4\% do seu valor total em 2010.

A Tabela abaixo demostra o volume total de créditos de carbono, por espécie, transacionados no mercado, identificados de acordo com os diferentes ambientes de negociação:

Com base nos dados expostos, observa-se um crescimento bastante elevado dos esquemas voluntários em comparação aos mercados formais. Nota-se que apesar do levantamento considerar o EU ETS um ambiente de formal de comércio de emissões, fato é que o esquema de negociação europeu tem em sua origem natureza voluntária, conforme será demonstrado adiante.

\footnotetext{
${ }^{32}$ Back to the Future: State and Trends of the Voluntary Carbon Markets 2011, Ecosystem Marketplace, Bloomberg New Energy Finance
} 


\begin{tabular}{|l|c|c|c|}
\hline \multicolumn{4}{|c|}{ Transaction Volumes and Values, Global Carbon Market, 2009 and 2010} \\
\hline
\end{tabular}

Fonte: Ecosystem Marketplace, Bloomberg New Energy Finance

\section{Tabela 1: Volume de Transações no Mercado Global de Carbono}

Atualmente, os principais centros voluntários de comercialização de créditos de carbono, sejam estes admitidos ou não no âmbito do Protocolo, estão situados na Europa, Estados Unidos e Oceania, operando em sua maioria sob o sistema cap and trade. Destacam-se neste cenário: (i) o Chicago Climate Exchange - CCX; (ii) o United Kingdom Emission Trading Schemes - UK ETS; e (iii) o European Union Emission Trading Scheme. 


\subsubsection{Chicago Climate Exchange - CCX}

Apesar dos Estados Unidos não terem ratificado o Protocolo de Quioto, o país possui um dos mais conceituados programas voluntários de negociação de créditos de carbono no mundo, denominado Chicago Climate Exchange - CCX. Desenvolvido em 2003 a partir da iniciativa de empresas e instituições públicas norte-americanas, o CCX Program, como é conhecido, funciona como um mercado de negociação de diversos ativos relacionados a projetos voluntários de baixo carbono, além de operar sob um sistema próprio de cap and trade.

De acordo com as regras vigentes da CCX, seus membros estariam sujeitos a "voluntary, but legally binding commitments", donde se extrai que os participantes se submetem aos compromissos de forma voluntária, porém, uma vez efetivada a adesão, as metas estariam sujeitas à regulação.

A primeira edição do programa foi realizada entre 2003 e 2010, período este que se dividiu em duas fases. Durante a Fase I, compreendida entre 2003 e 2006, as metas de redução aplicáveis aos membros eram de pelomenos $1 \%$ por ano, totalizando,ao final do período, um percentual mínimo de 4\% abaixo da linha de base (calculada com base nas emissões observadas entre 1998 e 2000). Na Fase II (2006 - 2010), os membros comprometeram-se a reduzir 6\% de suas emissões em relação à linha de base (1998-2000).

O principal crédito de carbono negociado no âmbito do Chicago Climate Exchange - CCX é o Carbon Financial Instrument, que de acordo com o padrão internacional de medição de emissões, correspondente a 100 toneladas métricas de carbono. A regulamentação dos procedimentos de verificação e certificação de projetos com potencial de redução de emissões é de responsabilidade do Conselho Executivo da CCX (CCX Executive Board), ao qual também compete designar as entidades autorizadas a representa-la nas esferas locais dos países.

No Brasil somente a Fundação Brasileira para Desenvolvimento Sustentável (FBDS) está autorizada a representar o Conselho Executivo, sendo assim responsável pela seleção, análise e encaminhamento dos projetos brasileiros interessados em participar do CCX Program. Segundo a 
FBDS (2011), são consideradas atividades com potencial de geração de créditos de carbono, aquelas que promovam, alternativamente: (i) a redução das emissões provenientes da queima de combustíveis fósseis; (ii) a substituição de combustíveis fósseis por energia limpa e renovável, como eólica, solar, biomassa, PCH etc; ou (iii) o aproveitamento das emissões que seriam de qualquer forma descarregadas na atmosfera (metano de aterros sanitários), para a produção de energia.

Ainda de acordo com a FBDS, as empresas brasileiras que aderirem ao programa de mercado de Chicago poderão cumprir seus compromissos de redução de emissões mediante a utilização dos seguintes meios: (a) investimentos em tecnologias limpas de processos produtivos; (b) compra de créditos de carbono de outras empresas participantes do CCX; e (c) aquisição de créditos de carbono de projetos no Brasil.

Na primeira edição do CCX Program somente foram aceitos projetos da região do NAFTA (Estados Unidos, Canadá e México) e do Brasil. No entanto a perspectiva é de que o novo programa, que entrará em vigor em 2012, abra a oportunidade para que projetos oriundos da Austrália, Nova Zelândia, Chile, entre outros países sejam também elegíveis.

\subsubsection{United Kingdom Emission Trading Schemes - UK ETS}

O UK ETS, como é popularmente conhecido, foi o primeiro esquema voluntário de negociação de carbono a ser implementado no mundo ${ }^{33}$. Instituído no Reino Unido, o programa também se baseia na metodologia cap and trade, tendo como elemento de estímulo para adesão das empresas o fato de que o governo britânico oferece aos participantes descontos de até $80 \%$ nas taxas de energia do país em troca do comprometimento de redução de emissões.

Como instrumento auxiliar no cumprimento das metas estabelecidas, foi realizada, através de leilão, a emissão primária de permissões correspondentes a 4.028.176 toneladas de carbono,

\footnotetext{
${ }^{33}$ Disponível em http://www.decc.gov.uk/en/content/cms/emissions/ccas/uk ets/uk ets.aspx (acesso em 01.11.2011)
} 
distribuídas entre 33 participantes, que a partir daí puderam comercializar créditos de carbono entre si, com o objetivo de alcançar suas respectivas metas.

Assim como o CCX, as metas neste caso são voluntárias, porém vinculantes, sendo que a sanção pelo descumprimento dos compromissos de redução consiste no cancelamento do desconto referente à taxa de energia e na retomada das permissões outorgadas, impossibilitando assim que o participante inadimplente se beneficie da comercialização dos créditos ambientais. Em virtude das vantagens tributárias que o programa envolve, o UK ETS é classificado pelos estudiosos como um esquema fiscal de redução de emissões.

Finalmente, vale ressaltar que o Reino Unido é signatário do Protocolo de Quioto e membro integrante do seu Anexo I, circunstâncias estas que estimulam ainda mais o desenvolvimento de um mercado doméstico de permissões e reduções de emissão. Embora possua um mercado desenvolvido de ativos ambientais, a natureza jurídica dos créditos de carbono ainda é controvertida no direito britânico, havendo divergências entre os conceitos de licenças administrativas (permits) e de propriedade privada (property) ${ }^{34}$.

\subsubsection{European Union Emission Trading System - EU ETS}

Proposto originalmente em 2001, porém concebido apenas 4 (quatro) anos mais tarde, em 2005, o European Union Emission Trading System é hoje o principal e mais robusto esquema voluntário de comércio de créditos de carbono no mundo, com volumes de negociação diários que superam quaisquer outros mercados.

Apesar de reconhecidamente inspirado no Protocolo de Quioto, o EU ETS foi concebido de forma totalmente independente do tratado, e por esta razão é enquadrado pelos estudiosos no conceito de regime voluntário de negociação. Nada obstante, o EU ETS faz jus a sua classificação de sistema Kyoto Compliance, permitindo que as instituições incluídas no regime europeu negociem

\footnotetext{
${ }^{34}$ FINANCIAL MARKETS LAW COMITEE, Emission allowances: creating legal certaingly, (2005), Dinsponível em www.fmlc.org
} 
certificados de MDL com o objetivo de atender seus compromissos de redução no âmbito do esquema regional. Essa interação se fez possível a partir de 2004, com a implementação do mecanismo denominado Linking Directive.

Os créditos carbono transacionados no âmbito do EU ETS são unidades representativas de permissões de emissões, formalmente denominados European Union Allowances - EUA, as quais concedem a seu portador o direito de liberar 1 (uma) tonelada de dióxido de carbono, ou equivalente (CO2e) na atmosfera.

O plano de redução de emissões instituído pelo EU ETS prevê três fases. A primeira etapa (Fase I), compreendida entre 2005 e 2007, abrangeu aproximadamente 40\% das permissões relacionadas aos setores de energia, metal e aço, papel e celulose, cimento, cerâmica e vidros. Neste primeiro momento, apenas as emissões de dióxido de carbono (CO2) foram objeto de regulação, tendo sido disponibilizado um total de $95 \%$ das EUAs aos países membros, para distribuição doméstica de acordo com os respectivos planos nacionais de alocação. A meta total de redução de emissões para a Fase I ficou estabelecida em 5\%. A multa aplicável na hipótese de descumprimento das metasprevistas na Fase I correspondem a $€ 40$ (quarenta euros) por tonelada excedente de $\mathrm{CO} 2$.

A segunda fase do EU ETS teve início em 2008 e segue até 2012, coincidindo assim com o primeiro período de compromisso do Protocolo. Já nesta segunda etapa são abrangidos todos os GEE, tendo sido estabelecida a meta de redução de $10 \%$ para todos os setores da indústria. A sanção por descumprimento, neste caso, é mais rigorosa: 100,00 euros por tonelada excedente de CO2. Outra peculiaridade do período é que, em virtude da regulamentação do Linking Directive em 2004, passou-se a admitir que as metas de redução fossem atingidas através da utilização tanto das RCEs, obtidas por meio do MDL, como das UREs, oriundas de projetos de Implementação Conjunta.

Por fim, a Fase III do EU ETS, que se estenderá entre 2013 e 2020, terá seus limites de emissões definidos com base nos resultados observados nas Fases I e II. Uma novidade que deve 
ser implementada pela Comissão Europeia nesta terceira etapa é a adoção do sistema de leilão para emissão primária de EAUs, ao invés da distribuição gratuita, conforme vinha sendo realizada.

\subsubsection{Outros Mercados em Formação}

Além dos esquemas descritos acima, todos já fomentados e em pleno funcionamento, existem ainda uma dezena de outros mercados voluntários recém-formados ou em processo de implementação no cenário mundial. A demanda social por medidas sustentáveis por parte dos governos afeta tanto os países integrantes do Anexo 1 do Protocolo, quanto aqueles que sequer possuem compromissos de redução, pressionando as autoridades a adotarem esquemas domésticos de negociação permissões e reduções de emissões baseados nos princípios cap and trade.

Nesse contexto, países como Japão, Canadá, México e Brasil passaram a desenvolver seus próprios mercados de negociação de créditos de carbono. No Japão e no Brasil, como veremos a seguir, o mercado encontra-se em fase de constituição, podendo ser observadas as primeiras iniciativas rumo à formação de um esquema de comércio nacional. Canadá e México, por sua vez, já consolidaram as estruturas básicas que norteiam seus respectivos mercados, restando agora aguardar o seu pleno desenvolvimento, que virá com o passar dos anos.

A criação de um esquema doméstico de comercialização de créditos de carbono no Japão vem sendo discutida entre os governantes desde 2003, contudo, até o momento não há nenhum sistema de negociação de reduções de emissão operando no país. O esquema piloto proposto pelo primeiro-ministro Yasuo Fukuda em junho de 2005, prevê a adoção de um sistema cap and trade, que possibilitaria a negociação de créditos sob o Mecanismo de Desenvolvimento Limpo do Protocolo de Quioto. A proposta encontra-se atualmente em fase de testes entre as empresas nipônicas e a expectativa é de que o programa seja lançado no início de 2013.

Compartilhando da mesma condição de membro do Anexo 1 mantida pelo Japão, o Canadá encontra-se em um estágio mais avançado de desenvolvimento no mercado de emissões. Proposto 
pelo governo em 2006, o Canadian Emissions Trading Schem e iniciou suas operações em 2010, tendo como principal objetivo para o primeiro período de vigência (2010 - 2020) alcançar uma redução 20\% das emissões de GEE em relação aos níveis observados em 2006. Segundo as regras do programa canadense, além da compra de créditos excedentes de emissões, os participantes poderão se utilizar de diversos instrumentos para cumprir as obrigações de redução impostas, tais como a compra de RCEs gerados a partir de MDL (limitados a 10\% das metas anuais),e a realização de contribuições ao Technology Fund, fundo mantido pelo governo canadense destinado ao financiamento de projetos sustentáveis MDL (limitado a 10\% das metas anuais).

Mesmo desvinculado de compromissos no âmbito do Protocolo de Quioto, o México teve a inciativa de estabelecer o primeiro programa voluntário de redução de emissões entre os países não integrantes do Anexo I do documento. Desde 2004 funciona no país o Mexico Greenhouse Gas Program, esquema doméstico de controle voluntário de emissões. Até 2010, passados seis anos de vigência do programa, os resultados obtidos mostraram-se surpreendentes para um país sem metas de redução impostas pela CQNUMC: um total de 125 empresas inscritas e 140 milhões de toneladas de CO2e contabilizadas.

\subsection{O Mercado de Carbono no Brasil}

O fato de possuir uma economia em pleno desenvolvimento somado à disponibilidade territorial e geográfica do país para receber os mais diversos tipos de projetos sustentáveis, faz do Brasil, na visão dos especialistas, um protagonista no combate ao aquecimento global. Não é novidade que o Brasil desponta no cenário mundial como um dos maiores fornecedores de Reduções Certificadas de Emissões (MDL) para os países desenvolvidos preocupados em atingir suas metas de redução, fazendo-se necessária a utilização de esquemas de negociação consolidadas em outros países para formalizar tais operações.

Na opinião dos analistas, as contribuições nacionais para o mercado global de carbono não se limitariam à geração de créditos de carbono em seu território, haveria ainda uma demanda local 
suficiente para justificar a criação de um mercado brasileiro de carbono ${ }^{35}$. Assim, aimplementação de uma plataforma de comércio de emissões no Brasil não só é compatível com políticas nacionais de controle de emissões como também constitui o instrumento que carece ao país para atingir o seu pleno potencial de geração de créditos de carbono.

Nesse sentido, a BM\&F Bovespa estuda projetos para instituição de um mecanismo de comércio de emissões no Brasil. Os relatórios divulgados pela Bolsa, levantados em parceria com a FINEP e o Banco Mundial, sugerem que a estrutura mais adequada para atender ao mercado doméstico seria um sistema privado e autorregulatório, de adesão voluntária, a ser denominado Sistema Brasileiro de Controle de Carbono (SBCC). De acordo com o material, o mercado brasileiro funcionaria sob os sistemas cap and trade e baseline-and-credit ${ }^{36}$, com adoção de metas de redução de emissões de gases de efeito estufa consolidadas nacionalmente, permitindo-se aos seus membros cumprir com seus compromissos através da comercialização de ativos ambientais na forma de dois títulos transacionáveis, o Direito de Emissão de Carbono (DEC) e a Obrigação de Remoção de Carbono $(\mathrm{ORC})^{37}$. A estimativa preliminar do estudo situa a dimensão do mercado dos ativos do SBCC na ordem de 1 bilhãode tCO2e anuais para o ano 2020 que, aos atuais preços internacionais, corresponderia a US\$18 bilhões anuais em transações.

As iniciativas da Bovespa, por enquanto, não passam de projeções, sendo que as principais ações relacionadas ao mercado de carbono promovidas pela Bolsa até o momento foram leilões de

\footnotetext{
${ }^{35}$ Organização do Mercado Local de Carbono: Sistema Brasileiro de Controle de Carbono e Instrumentos Financeiros Relacionados

${ }^{36} \mathrm{O}$ sistema de linha de base e crédito (baseline-and-credit) está apoiado na implementação de projetos que reduzam as emissões além do cenário usual projetado, originando créditos de carbono. Fonte: Organização do Mercado Local de Carbono: Sistema Brasileiro de Controle De Carbono e Instrumentos Financeiros Relacionados

${ }^{37} \mathrm{O}$ DEC corresponde à permissão clássica (allowances) dos sistemas cap-and-trade hoje conhecidos. É um título representativo da autorização do SBCC para que determinada fonte emita gases de efeito estufa, alocado em volumes limitados, refletindo, portanto, a obrigação voluntariamente assumida pela fonte de reduzir suas emissões, conforme os limites setoriais fixados pelo sistema. Já a ORC é um ativo inovador, proposto neste estudo para ampla discussão no cenário brasileiro, país que tem importante potencial de remoção de carbono da atmosfera, principalmente através do setor de atividades florestais, no qual é muito competitivo internacionalmente. A ORC é o título representativo da obrigação de remover carbono da atmosfera, aceitavoluntariamente pelo participante. Será alocado às fontes que, pela sua natureza, promovem a remoção, conforme as metas setoriais estabelecidas pelo sistema. Fonte: Organização do Mercado Local de Carbono: Sistema Brasileiro de Controle De Carbono e Instrumentos Financeiros Relacionados
} 
créditos de carbono de pouca expressão. Para se ter uma ideia, mais recente certame organizado pela BM\&F em 08/04/2010, no qual foram ofertadas 180 mil unidades de reduções de emissões verificadas (voluntary carbono units), terminou sem interessados em arrematar os créditos de carbono $^{38}$. Convém ressaltar ainda que, dada à importância do tema e considerando as perspectivas promissoras para o país no setor, as medidas brasileiras podem ser avaliadas como tardias se compararmos, por exemplo, com o caso do México, que mesmo não fazendo parte do Anexo I do Protocolo como o Brasil, já possui um esquema próprio de negociação.

Apesar das críticas, é preciso reconhecer que a consolidação do mercado brasileiro de carbono não depende somente da iniciativa dos agentes de mercado, o processo de formação demanda uma atividade legislativa que foge à alçada de competência das entidades particulares. Com efeito, conforme será abordado nos tópicos seguintes, o atual estágio de regulamentação do setor ainda precisa evoluir para evitar que o mercado de emissões brasileiro se desenvolva num ambiente de incertezas. Essa imaturidade normativa fica evidente quando nos deparamos com elevado número projetos de lei em tramitação no Congresso Nacional.

\subsubsection{Aspectos regulatórios do mercado de carbono brasileiro}

Como vem sendo enfatizado no decorrer deste trabalho, a construção normativa destinada à disciplina do mercado de carbono no âmbito nacional ainda encontra-se em estágio inicial de implementação, servindo apenas para nortear as iniciativas no setor. Inúmeras são as carências e as lacunas verificadas no arcabouço normativo que define as políticas de controle de emissões de GEE no Brasil.

Nesse contexto, um importante passo foi dado rumo à implementação do mercado voluntário de carbono no Brasil. Trata-se da promulgação da Lei Federal 12.187, de 29 de dezembro de 2009, que institui Política Nacional de Mudança do Clima (PNMC) e dá outras

\footnotetext{
${ }^{38}$ Notícia veiculada no site www.bmfbovespa.com.br/pt-br/noticias/2010/Leilao-de-creditos-de-carbono-termina-semnegocio-2010-04-08.aspx?tipoNoticia=1\&idioma=pt-br (acesso em 02.11.2011)
} 
providências. Dentre as medidas de enfrentamento das alterações climáticas previstas na PNMC destaca-se o estabelecimento de metas de redução de emissões de GEE:

"Art. 12. Para alcançar os objetivos da PNMC, o País adotará, como compromisso nacional voluntário, ações de mitigação das emissões de gases de efeito estufa, com vistas em reduzir entre $36,1 \%$ (trinta e seis inteiros e um décimo por cento) e 38,9\% (trinta e oito inteiros e nove décimos por cento) suas emissões projetadas até $2020 .^{39 \prime \prime}$

Nota-se que, seguindo a tendência dos esquemas de negociações instituídos pelo mundo, a lei confere caráter voluntário aos compromissos de redução de emissões aplicáveis às entidades locais, donde se conclui que o mercado resultante terá características de mercado voluntário. Nada impede, no entanto, que o mesmo possa evoluir sistema mandatório ao longo do tempo. Frise-se, contudo, que embora não o faça expressamente, a lei também prevê a necessidade de regulação do mercado de carbono no Brasil, o que não lhe retira o caráter voluntário.

\subsubsection{Mercado Brasileiro de Reduções de Emissões - MBRE}

Outra questão de importante regulada pelo PNMC diz respeito ao Mercado Brasileiro de Redução de Emissões, que é definido pela Lei Federal 12.187/09 como um instrumento alternativo para o cumprimento dos compromissos nacionais, dispondo o artigo 9o do referido normativo nos seguintes termos:

“Art. 9o O Mercado Brasileiro de Redução de Emissões será operacionalizado em bolsas de mercadorias e futuros, bolsas de valores e entidades de balcão organizado, autorizadas pela Comissão de Valores Mobiliários - CVM, onde se dará a negociação de títulos mobiliários representativos de emissões de gases de efeito estufa evitadas certificadas."

\footnotetext{
${ }^{39}$ Disponível em http://www.planalto.gov.br/ccivil_03/_ato2007-2010/2009/lei/l12187.htm
} 
Muito embora seja a primeira vez que o MBRE é abordado em âmbito normativo, não é através da Lei do PNMC que ocorre sua concepção. O Mercado Brasileiro de Redução de Emissões foi originalmente lançado em 2005, a partir de um convênio celebrado entre o Ministério do Desenvolvimento, Indústria e Comércio Exterior (MDIC) e a BM\&F Bovespa com o objetivo de desenvolver um sistema eficiente de negociação de créditos de carbono, em consonância com os princípios do Protocolo de Quioto.

As principais iniciativas do convênio consistiram na implantação de um Banco de Projetos e um Sistema de Negociação de Créditos de Carbono. A ideia do banco de projetos envolve a criação de um sistema eletrônico de registro de projetos com potenciais de geração de RCEs, de acordo com os critérios e procedimentos estabelecidos pelo MDL. Numa etapa seguinte foi estabelecido o Sistema de Negociação de Créditos de Carbono, um ambiente transparente de negociação de créditos de carbono a termo e a vista.

Assim, não se está criando o MBRE a partir da adoção da PNCM, posto que o mercado brasileiro já era uma realidade. O que se pretende com a edição da Lei Federal 12.187/09 é na verdade promover o MBRE, buscando fomentá-lo de acordo com diretrizes da PNCM, ficando claro esse objetivo quando em seu artigo 4으 a referida lei determina que "a Política Nacional de Mudanças Climáticas visará estimular e desenvolver o Mercado Brasileiro de Redução de Emissões". 


\section{CONCLUSÃO}

As últimas décadas representaram um importante divisor de águas no tocante à temática ambiental. A intensificação do efeito estufa e as conseqüências danosas desse fenômeno no ecossistema terrestre tornaram-se assuntos recorrentes na pauta das discussões mundiais. Restou demonstrado que a perpetuação da espécie humana demandaria, necessariamente, a adoção de princípios do desenvolvimento sustentável, fazendo com que os governos repensassem suas políticas de crescimento econômico.

Em meio a este cenário conturbado de conscientização ecológica, o Protocolo de Quioto se consolidou como uma solução inovadora no ambiente jurídico internacional, uma vez que se mostrou capaz de conciliar normas de proteção ambiental com princípios de mercado sem precedentes. Se por um lado, a adesão em massa a um documento formal estabelecendo obrigações ambientais vinculantes sinalizou o comprometimento das nações e dos principais organismos internacionais em combater o aquecimento global, por outro, representou o sucesso dos mecanismos de mercado auxiliares do Protocolo junto aos agentes financeiros, que visualizaram nestes instrumentos de flexibilização uma nova modalidade de comércio internacional.

Nem mesmo a resistência de alguns países em aderir aos mecanismos imperativos de redução de emissões de GEE impediu a formação de um importante e próspero mercado de ativos ambientais. Ao contrário, o que se observou com a entrada em vigor do Protocolo foi uma sucessão de iniciativas locais e regionais com vistas a instituir programas voluntários de redução de emissões nos mesmos moldes do sistema instituído pelo Protocolo, porém completamente independentes deste. Um exemplo curioso desse movimento ocorreu nos Estados Unidos, que, mesmo não tendo ratificado o Protocolo de Quioto, acolhe um sofisticado programa de controle de emissões e comercialização de créditos de carbono dotado de estrutura semelhante ao modelo previsto no tratado, com a ressalva de que no caso americano os compromissos não são compulsórios. 
Apesar dos entraves iniciais, tudo indica que estamos testemunhando o nascimento de um novo mercado de proporções mundiais. Neste ambiente de negociações de nível global, os principais produtos transacionáveis são títulos representativos de reduções ou permissões de emissão de GEE, os quais podem assumir diferentes classificações e nomenclaturas, de acordo com a origem, forma de aquisição e esquema de comércio ao qual fazem parte (CERs, ERUs, AAUs, EUAs e CCAs). Contudo, a tendência é que tais classificações percam a utilidade prática, pois existe a necessidade de se conferir um caráter fungível aos créditos de carbono, de modo a atender interesses econômicos, permitindo assim que os mercados operem com volumes maiores de negócios. Isso se deve principalmente ao fenômeno de integração dos programas autônomos de comercialização de créditos de carbono, que permite a livre circulação de diferentes espécies de ativos ambientais que compõem o mercado de carbono, como ocorreu no convênio firmado entre os órgãos da EU ETS e do Protocolo de Quioto.

Com base nos esquemas de negociação abordados, inferimos que todos os programas de comercialização de emissões são estruturados ou sob o formato de limite e comércio de emissões (cap-and-trade) ou sob o modelo de linha de base e crédito, o que denota a necessidade de se estabelecer uma motivação econômica ou jurídica no sentido de estimular a adesão de participantes aos compromissos de redução, não sendo suficiente o apelo ambiental para garantir o sucesso dos programas.

Vimos então, nesse contexto, que uma forma peculiar de incentivar a adesão de empresas aos mecanismos de controle de emissões consiste na concessão de benéficos fiscais àqueles que ingressarem nestes esquemas, estratégia esta que hoje em dia é utilizada apenas no âmbito do UK ETS, mas que se revela como um instrumento eficiente de aprimoramento da demanda por créditos de carbono nos mercados voluntários.

Ainda no âmbito dos mercados voluntários internacionais, verifica-se que as incertezas que envolvem os aspectos jurídicos relacionados aos créditos de carbono afastam alguns investidores interessados em aplicar recursos no setor, retardando o pleno desenvolvimento do mercado. Como visto, poucos são os países que já definiram o enquadramento jurídico dos créditos de 
carbono nos ordenamentos locais, sendo que, entre os que já o fizeram, fica nítido em alguns casos que a adoção de determinado conceito jurídico se deu em razão de interesses meramente políticos e não seguiram um padrão normativo, como a lógica supõe. Este é o caso da China, onde os créditos de carbono foram definidos como recursos naturais pertencentes ao estado. Dessa forma, o direito comparado se mostrou uma alternativa ineficiente para auxiliar a construção de um conceito jurídico sólido para as RCEs.

No Brasil não é diferente, a falta de definição da natureza jurídica dos créditos de carbono tem provocado insegurança para o mercado brasileiro. Esse cenário de indefinições decorrente do vazio regulatório sobre a questão no âmbito nacional também têm prejudicado o florescimento do mercado doméstico.

Conforme foi assinalado durante exposição do tema, ainda existe muita divergência entre os especialistas em relação ao enquadramento jurídico dos créditos de carbono, o que se deve, principalmente, à pendência de edição de marco legal específico sobre a questão. Mesmo os projetos de lei que atualmente tramitam nas casas legislativas possuem abordagens distintas sobre a natureza jurídica mais adequada aplicável às RCEs e instrumentos correlatos.

A partir dos conceitos importados das ciências econômicas, bem como das manifestações doutrinárias sobre o assunto, foram identificadas cinco diferentes classificações jurídicas para as RCEs, as quais se dividem nos planos lato sensu e strictu sensu, sendo que são excludentes entre si apenas as definições pertencentes ao mesmo plano, são elas: (i) bem incorpóreo ou intangível; (ii) ativo; (ii) derivativo; (iv) commodity ambiental; (v) título ou valor mobiliário; (vi) contrato de prestação de serviços.

Contudo, tendo em vista a amplitude do conceito conferido às RCEs e demais créditos de carbono nos tratados e acordos internacionais, pouco se pode concluir em relação ao correto enquadramento jurídico destes instrumentos no direito doméstico. A vagueza na definição das propriedades básicas dos créditos de carbono permite que o legislador pátrio, ao incorporar o instituto a ordenamento jurídico interno, interprete suas características e amolde seu conceito de 
acordo com a natureza jurídica que se pretenda adotar, motivado apenas pelos efeitos econômicos que tal definição pode acarretar.

Isso posto, considerando a estrutura do mercado de carbono que se forma no Brasil, nos parece que a natureza jurídica que melhor promove a inserção dos créditos de carbono no sistema financeiro é sua classificação como valores mobiliários, na condição de instrumento derivativos, conforme previsão contida na Lei no 6.385, DE 7 DE dezembro de 1976.. Ademais, do ponto de visto jurídico a definição dos créditos de carbono como derivativos e, consequentemente, sua inclusão no conceito de valores mobiliários, se mostra consentânea com a legislação e os normativos expedidos pela CVM, havendo amparo tanto normativo quanto doutrinário neste sentido. Em todo caso, tais conceitos ainda constituem construções didáticas, sendo necessária a edição de legislação ou posicionamento das autoridades competentes para que se possa afirmar de forma precisa a natureza jurídica adequada.

Em que se pese nossa despretensiosa opinião, a Comissão de Valores Mobiliários (CVM), autarquia responsável pela regulação do mercado de capitais, já emitiu pronunciamento acerca da conotação jurídica das RCEs através do voto emitido pelo seu diretor Otávio Yazbek no âmbito do processo administrativo CVM n. RJ 2009/6346. Apesar de ser enfático ao determinar que as RCEs não se caracterizam como valores mobiliários, o voto peca ao deixar de definir a natureza jurídica de tais ativos, forçando uma conclusão no sentido de que o tema permanece em aberto, aguardando uma iniciativa legislativa sobre a matéria.

No que se refere à regulamentação das RCEs no mercado de capitais, a Lei 12.187/09 representa um avanço ao estabelecer as bases da regulação das RCEs no mercado de capitais. Contudo, trata-se de norma de caráter geral, que demanda a elaboração de leis complementares para operacionalizar os esquemas de mercado nacional. Ocorre, que desde a sua publicação, não foi possível estabelecer uma interpretação uniforme de seus termos, de modo que, ao que tudo indica, nem a CVM nem as casas legislativas consideram-se prontas para expedir normas realmente esclarecedoras sobre o tema. 
Enfim, apesar de já existir uma plataforma organizada de negociação de créditos de carbono, o MBRE, não foi possível ainda se estabelecer com clareza de que forma tais operações se inserem no âmbito de regulamentação da CVM, sendo que, por conta disso, a maior parte das transações envolvendo ativos ambientais são atualmente negociadas diretamente entre as partes interessadas, fora dos mercados de bolsa e balcão organizado, que em tese seriam ambientes mais adequados para a comercialização destes títulos.

\section{REFERÊNCIAS BIBLIOGRÁFICAS}

ALMEIDA, H.N.N. Créditos de carbono: natureza jurídica e tratamento tributário. Disponível em: < http://jus2.uol.com.br/doutrina/texto.asp?id=7307 (acesso em 09.10.2011).

BARBOSA, Rangel; OLIVEIRA, Patrícia. O Princípio do Poluidor-Pagador no Protocolo de Quioto. Revista de Direito Ambiental. São Paulo, n 44, 2006

CAMARGO, Camila de, Mercado de carbono do protocolo de Quioto: principais aspectos e tributação, Orientador Prof. Ms. Argos Magno de Paula Gregório; Tese apresentada Universidade Presbiteriana Mackenzie em 2010.

CARVALHOSA, Modesto, A nova Lei das Sociedades Anônimas, São Paulo : Saraiva, 2002

CASARA, Ana Cristina. Direito Ambiental do Clima e Créditos de Carbono. São Paulo: Juruá.

FILHO, ARY OSWALDO MATTOS. Revista de Direito Mercantil- Industrial, Econômico e Financeiro. N. 59 
FRANGETTO, Flavia Witkowski; GAZANI, Flavio Rufino. Viabilização Jurídica do Mecanismo de Desenvolvimento Limpo (MDL) no Brasil: O Protocolo de Kyoto e a cooperação internacional. São Paulo: Fundação Peirópolis, 2002.

GABEIRA, F. Sob o signo de Kyoto- commodities ambientais: as sementes estão lançadas. JB Ecológico, Rio de Janeiro, n. 38, p. 53, mar. 2005.

LIMIRO, Danielle. Créditos de Carbono - Protocolo de Kyoto e Projetos de MDL. São Paulo: Juruá.

NETO, Antonio Lorenzoni. Contrato de Créditos de Carbono - Análise Crítica das Mudanças Climáticas. São Paulo: Jurua

NETO, Werner Grau. O Protocolo de Quioto e o Mecanismo de Desenvolvimento Limpo - MDL: Uma análise crítica do instituto. São Paulo: Editora Fiuza, 2007.

OLIVEIRA, Carlos Frederico Saturnino de; BOCAIUVA, Adriana. Protocolo de Quioto, mecanismos de desenvolvimento limpo, créditos de carbono. Aspectos jurídicos. Rio de Janeiro: Revista Forense, 380 vol.

PARTNOY, Frank/ SKEEL, David, Promises and Perils of Credit Derivatives, in: 75 "University of Cincinnati Law Review" (2007)

SISTER, Gabriel. Mercado de Carbono e Protocolo de Quioto - Aspectos Negociais e Tributários. São Paulo: Campus.

SABBAG, Bruno Kerlakian. O Protocolo de Quioto e seus Créditos de Carbono. São Paulo: Ltr, 2009 
SOUZA, Antonio Mello e, et al. Regulamentação dos Ativos Ambientais no Brasil. Banco Mundial, BM\&F Bovespa e FINEP. 2010.

SOUZA, Clóvis S. de; MILLER, Daniel Schiavoni. O Protocolo de Quioto e o Mecanismo de Desenvolvimento Limpo (MDL): As Reduções Certificadas de Emissões (RCEs), sua natureza jurídica e a regulação do mercado de valores mobiliários, no contexto estatal pós-moderno. Comissão de Valores Mobiliários - CVM, 2003.

SOUZA, Rafael Pereira de, et al. Lexnet. Aquecimento Global e Créditos de Carbono: Aspectos jurídicos e Técnicos. São Paulo: QuartierLatin, 2007.

VARELLA, Dias Marcelo. Direito Internacional Econômico Ambiental. Belo Horizonte: Del Rey, 2003 